University of Nebraska - Lincoln

DigitalCommons@University of Nebraska - Lincoln

1982

\title{
Diatom Biostratigraphy and Paleoecology of the Type Section of the Luisian Stage, Central California
}

Jack G. Baldauf

USGS

John A. Barron

USGS

Follow this and additional works at: https://digitalcommons.unl.edu/usgsstaffpub

Part of the Earth Sciences Commons

Baldauf, Jack G. and Barron, John A., "Diatom Biostratigraphy and Paleoecology of the Type Section of the Luisian Stage, Central California" (1982). USGS Staff -- Published Research. 271.

https://digitalcommons.unl.edu/usgsstaffpub/271

This Article is brought to you for free and open access by the US Geological Survey at DigitalCommons@University of Nebraska - Lincoln. It has been accepted for inclusion in USGS Staff -- Published Research by an authorized administrator of DigitalCommons@University of Nebraska - Lincoln. 
Jack G. Baldauf

John A. Barron

U.S. Geological Survey

Menlo Park, California 94025

\section{Diatom biostratigraphy and paleoecology of the type section of the Luisian Stage, central California}

\section{INTRODUCTION}

Although recent studies have questioned the isochroneity of correlations based on benthic foraminiferal assemblages associated with the provincial benthic foraminiferal stages of Kleinpell (1938), benthic foraminifers remain the principal means of dating Cenozoic marine rocks in California. Crouch and Bukry (1979), using calcareous nannofossil biostratigraphy, documented an overlap of Kleinpell's Miocene benthic foraminiferal stages in the Southern California Continental Borderland. Benthic foraminiferal assemblages are often greatly controlled by environmental conditions, and McDougall (1979) has reported that the Narizian and Refugian stages of Mallory (1959) are partially coeval, representing specific ecological conditions rather than a difference of time. In response to this problem, micropaleontologists at the U.S. Geological Survey, Menlo Park, California, have chosen to reevaluate the provincial benthic foraminiferal stages of Kleinpell (1938) by studying in detail the microfossils of the type sections, with initial efforts directed toward the Relizian and Luisian stages.

During April 1979 a field party collected the type sections of the Relizian and Luisian stages in central California. No diatoms were found in Relizian and Luisian strata in Reliz Canyon; however, diatomaceous rocks are common in the type section of the Luisian Stage in San Luis Obispo County (Kleinpell, 1938), and our reconnaissance showed diverse and abundant assemblages.

The preliminary study by Addicott et al. (1978) represents the only published study of microfossils from the type section of the Luisian Stage. ${ }^{1}$ Only a few samples from the actual type section, however, were studied; the majority of samples came from a section along State Highway 58, a few miles to the east. Previous studies by Cushman (1926) and Lipps (1967) were limited to the study of foraminifers from adjacent areas. The preliminary study of the benthic foraminifers (McDougall), planktic foraminifers and coccoliths (Poore), and diatoms (Barron) in Addicott et al. (1978) provided a framework for collection and study by these workers of the type Luisian section. Although their assignment (in Addicott et al., 1978) of the type Luisian Stage to the early Middle Miocene supports previous assignments of Luisian rocks elsewhere in the state (Lipps, 1967; Lipps and Kalisky, 1972; Wornardt, 1973; Crouch and Bukry, 1979), a detailed study of the floras and faunas of the type Luisian section is needed for refined correlations and to establish the ecologic conditions.

The type section of the Luisian Stage is situated along "the prominant northwestward-draining gully in the extreme southwest corner of Section 21, T. 28 S., R. 14 E.," in the Wilson Corner 71/2-minute quadrangle, 


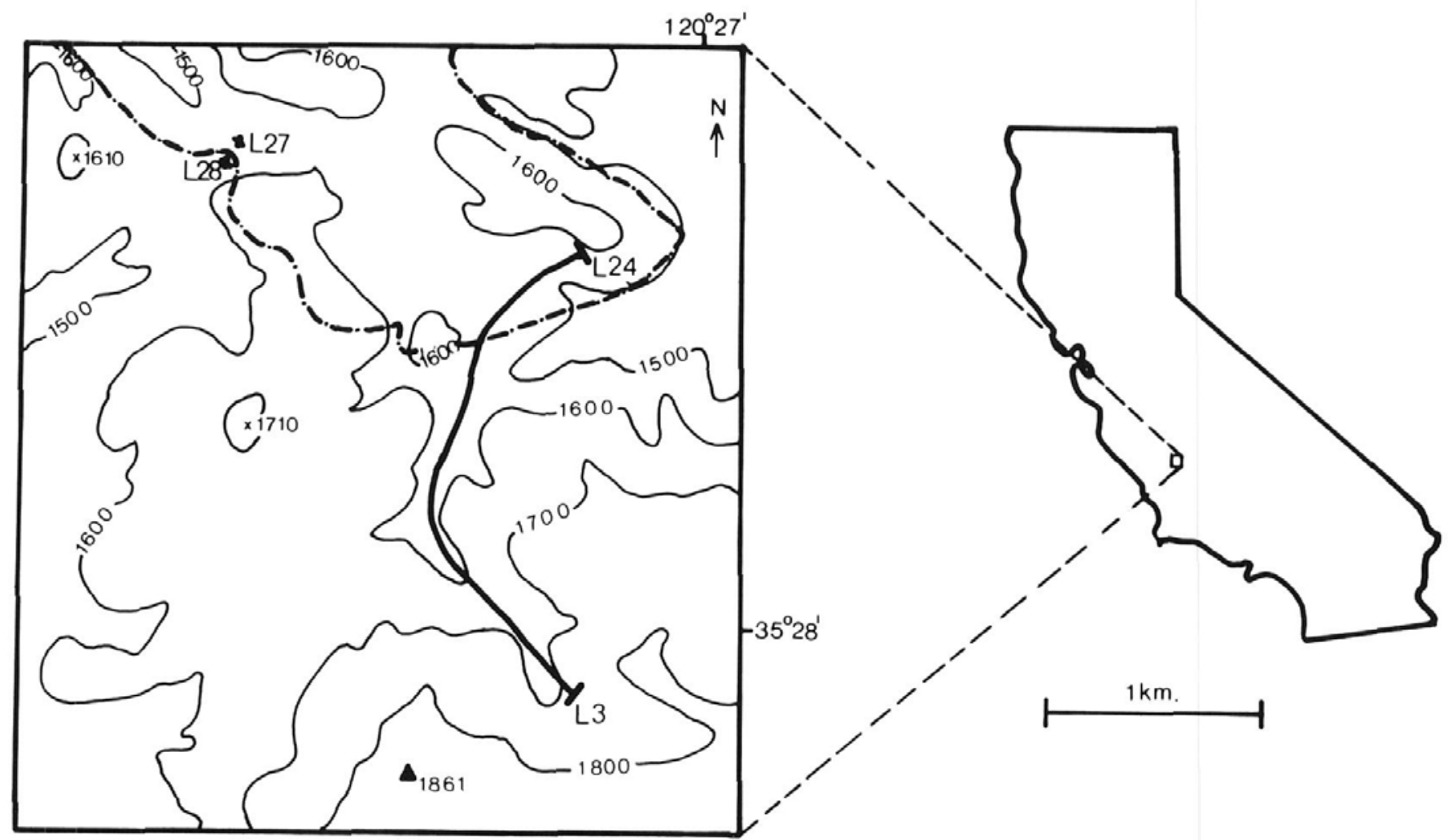

TEXT-FIGURE 1

Map showing location of samples collected from type section of Luisian Stage, sec. 21, T. 28 S., R. 14 E., Wilson Corner 71/2-minute quadrangle, California. Dotted line represents phosphatic siliceous shale bed marking top of type Luisian section of Kleinpell (1938). Contour interval shown in feet; scale shown is for contour map.

San Luis Obispo County, California (Kleinpell, 1938) (text-fig. 1). The base of the section is the horizon of the distinct lithologic change from clay shale to overlying diatomaceous shale, and the top is placed at the base of a prominent, 1.2-m-thick bed of phosphatic siliceous shale (text-fig. 2). The base of the section lies between sample L3, which is barren of diatoms, and overlying sample $L 2$, which contains abundant diatoms. Twenty-three samples from the type section, sample L2 through sample L27, were processed for diatoms, as were two overlying samples ( $L 28$ and L24) from the Hames Member of the Monterey Formation (text-fig. 2).

\section{MATERIALS AND METHODS}

These samples were processed in hydrogen peroxide and hydrochloric acid following the procedures of Barron (1976). Two strewn slides were prepared from each sample and were examined in entirety at $\times 500$. The first 300 diatoms observed in each sample were tabulated for their relative abundance. A species was recorded as abundant if it accounted for greater than $25 \%$ of the count, common if $16-24 \%$, few if $6-15 \%$, rare if $1-5 \%$, and present if less than $1 \%$, or if the species was observed independently of the counting.

Quality of preservation of each sample was based on the absence and presence of selected diatoms. Fine delicate taxa such as Synedra jouseana SheshukovaPoretzkaya, Rouxia diploneides Schrader, Thalassiothrix longissima Cleve and Grunow, and Mediaria splendida Sheshukova-Poretzkaya were used for determining well-preserved samples, whereas the presence only of heavily silicified forms such as Coscinodiscus marginatus Ehrenberg, Actinocyclus ingens Rattray, and Stephanopyxis spp. suggested poor preservation.

\section{RESULTS}

One hundred four taxa, characteristic of a nearshore marine environment, were recognized in the section (table 1). Both robust and finely silicified species occurred throughout the section, indicating a well-preserved assemblage. All taxa are typical of the early Middle Miocene of California, as described by Hanna (1932), Wornardt (1973), and Barron (1976). Taxonomic notes appear in the Appendix.

\section{Biostratigraphy}

Diatoms of the type Luisian Stage are assigned to the lower Middle Miocene Denticulopsis lauta Zone and the lowermost part of the Denticulopsis hustedtii-D. 
lauta Zone as emended by Barron (1980) (text-fig. 2). The assemblages also correlate with North Pacific Diatom Zones XXIII to XX of Barron (1976). The diatom assemblage of sample L2, the lowest sample of the type section, includes Denticulopsis sp. cf. D. lauta sensu Barron (1980), Rhaphoneis miocenica Schrader, $R$. parilis Hanna, and Raphidodiscus marylandicus Christian and is therefore suggestive of the basal assemblages of the $D$. lauta Zone as observed off Japan (Barron, 1980) and in the Southern California Continental Borderland (Barron, unpublished data).

The top of subzone " $a$ " and the base of subzone " $b$ " of the Denticulopsis lauta Zone is marked by the first occurrence of Denticulopsis hyalina (Schrader) Simonsen in sample L22. This subzonal boundary is recognizable in both offshore and onshore sections in the California area (Baldauf and Barron, 1980; Barron, 1981).

Denticulopsis hustedtii first occurs in sample L27 near the top of the section. Unfortunately, a 40-m-thick covered section below L27 prevents accurate placement of the boundary between the $D$. hustedtii-D. lauta and the $D$. lauta zones. Presumably, this boundary does not lie too far below sample L27, because the overlying samples L28 and L24 contain assemblages more typical of the lowermost portions of subzone "a" of the Denticulopsis hustedtii-D. lauta Zone including Coscinodiscus praeyabei Schrader, common Denticulopsis hyalina, and the absence of common Denticulopsis hustedtii (Simonsen and Kanaya) Simonsen.

The absence of Denticulopsis hustedtii from samples L28 and L24 above the common occurrence of D. hustedtii in sample 27 is not typical. The normal sequence observed throughout the middle latitudes of the North Pacific is initial sparse $D$. hustedtii followed upsection by more common and consistent occurrences of the species (Barron, 1981). The presence of Coscinodiscus plicatus Grunow and C. praeyabei in samples L28 and L24 ensure their assignment to the subzone " $a$ " of the Denticulopsis hustedtii-D. lauta Zone, so that the absence of $D$. hustedtii in samples above L27 evidently represents either ecological or preservational exclusion. The latter is doubtful, because relatively delicate taxa including Mediaria splendida, Rhizosolenia styliformis Brightwell, Rouxia diploneides, and Synedra jouseana occur in both samples.

Text-figure 3 shows the correlation of the diatom biostratigraphy of the type Luisian with the international time scale, planktic foraminiferal zones of Blow (1969), and coccolith zones of Bukry $(1973,1975)$. The time scale and zonal correlations are those adopted by Bukry, Poore, and Barron in Haq and Yeats et al. (in press) after study of material collected by DSDP Leg 63 off

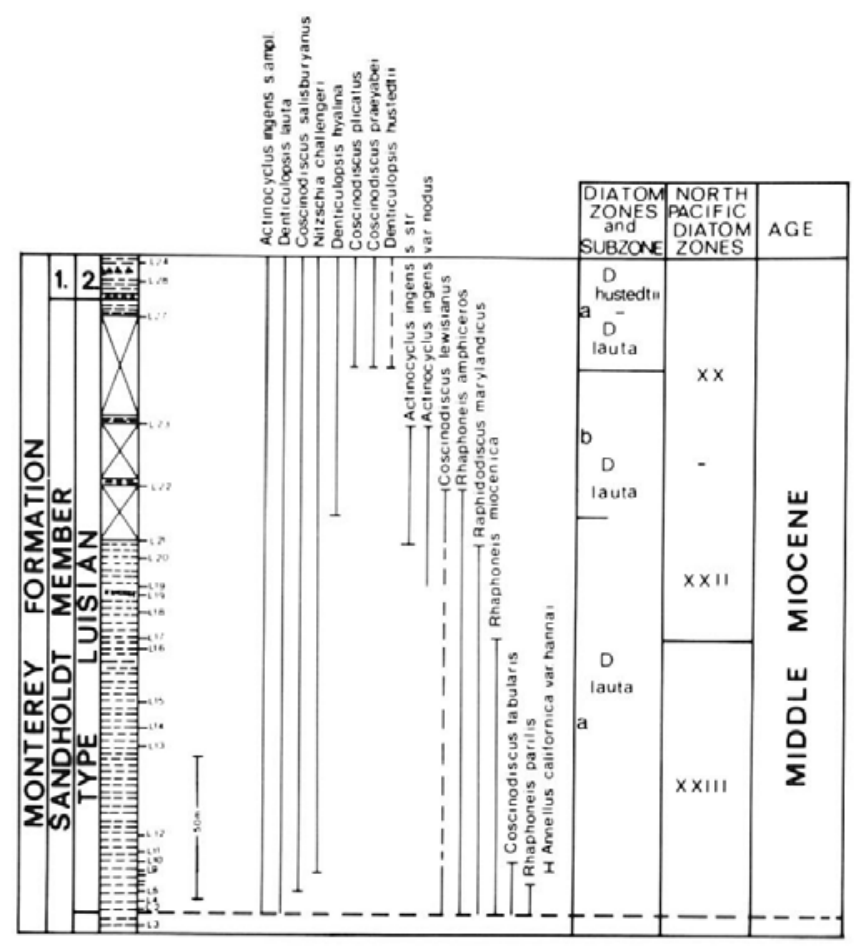

TEXT-FIGURE 2

Columnar section of type Luisian Stage showing stratigraphic distribution of samples, diatom biostratigraphy, and ranges of selected diatom taxa. Diatom zones and subzones from Barron (1980), left column, and North Pacific Diatom Zones from Barron (1976) and Schrader (1973), right column. 1, Hames Member. 2, Mohnian.

southern California and Baja California. Consequently, the type Luisian correlates with the early Middle Miocene between about 16.0 and $14.0 \mathrm{Ma}$, with planktic foraminifer Zones N8 through N11, and with the uppermost part of the Helicosphaera ampliaperta to lower part of the Discoaster exilis coccolith zones. These relations are supported by Poore's (in Addicott et al., 1978) study of Luisian coccoliths from the area, although Poore initially recognized only planktic foraminiferal Zones N8 and N9 in these rocks. Lipps's (1967) general correlation of Luisian rocks in California with the upper part of Zone N8 through the lower part of $\mathrm{N} 12$ is nearly identical with the correlation of the type section shown in text-figure 3 .

Time equivalence of rocks containing Luisian benthic foraminiferal assemblages was disputed in part by Crouch and Bukry (1979). Baldauf and Barron (1980) correlated the Luisian-Mohnian boundary of Warren (1972) in the Upper Newport Bay section, south of Los Angeles, with the uppermost part of the D. lauta Zone, a horizon slightly older than the top of the type Luisian section suggested by this study. In general, Luisian benthic foraminiferal assemblages have shown little diachroneity in relation to diatom biostratigraphy in strata studied by Barron (1976, unpublished data) from 
TABLE 1

Occurrence of diatom taxa in samples studied from type section of Luisian Stage. A-abundant, C—common, F-few, R-rare; + present but not recorded in counts of 300. Preservation: $\mathrm{G} \longrightarrow$ good, $\mathrm{M}$-moderate, $\mathrm{P}$-poor. See text for explanations.

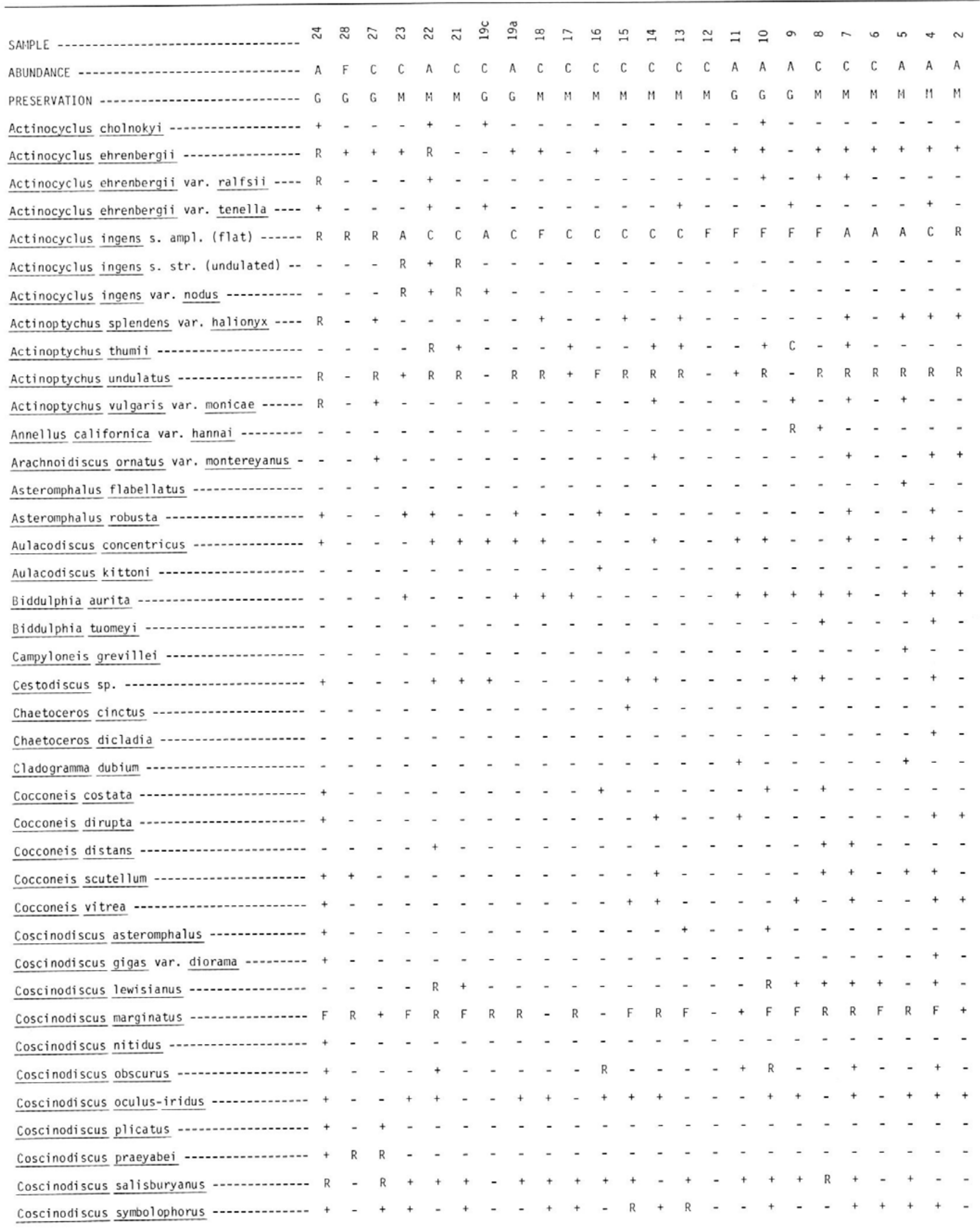




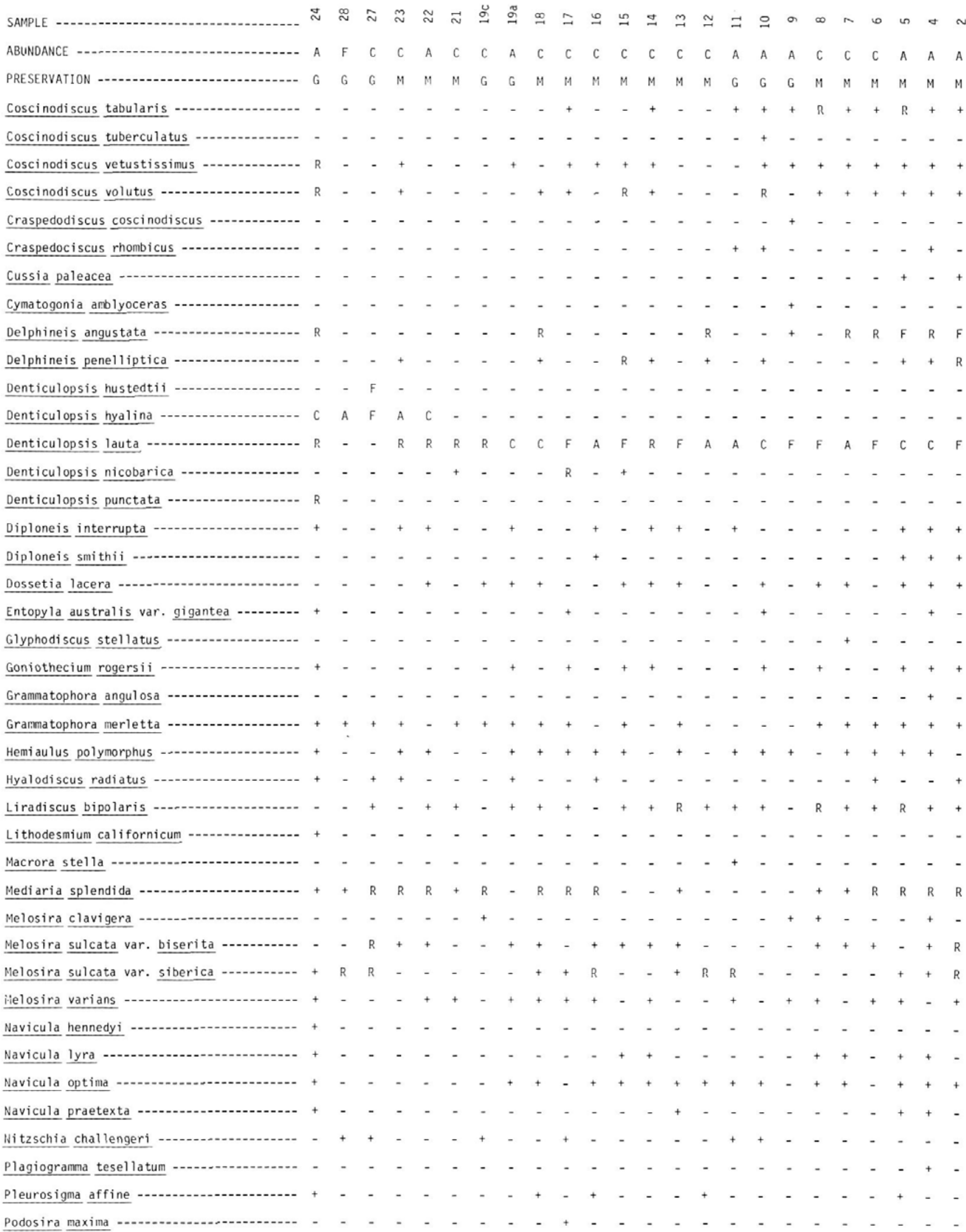


TABLE 1 (Continued)

\begin{tabular}{|c|c|c|c|c|c|c|c|c|c|c|c|c|c|c|c|c|c|c|c|c|c|c|c|c|}
\hline SAMPL & $\approx$ & $\stackrel{\infty}{N}$ & $\approx$ & $\stackrel{N}{\sim}$ & $\approx$ & $\vec{\sim}$ & 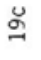 & $\stackrel{\overbrace{}}{~}$ & $\stackrel{\infty}{\rightarrow}$ & $=$ & $\stackrel{ }{-}$ & $\cong$ & 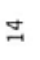 & $\rightarrow$ & $\cong$ & $\Xi$ & 오 & $\sigma$ & $\infty$ & n & 6 & in & 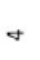 & $\sim$ \\
\hline ABUHDANCE --- & A & $\mathrm{F}$ & C & C & A & $\mathrm{c}$ & C & A & $c$ & $c$ & c & c & c & $c$ & c & A & A & A & c & C & c & A & A & A \\
\hline PRESERVATION -.-. & G & G & G & M & M & M & G & $G$ & $M$ & M & M & 11 & M & H & M & G & G & G & M & M & M & M & M & M \\
\hline Pseudopyxilla americana - & - & - & - & - & - & - & - & - & + & - & - & - & - & - & - & - & - & - & - & 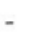 & - & - & + & - \\
\hline Raphidodiscus marylandicus - & - & - & - & - & - & $=$ & - & - & - & - & - & - & - & - & - & - & - & - & - & - & - & - & + & - \\
\hline Rhabdonema japiconicum - & + & - & - & - & - & - & - & - & - & - & - & - & - & - & - & - & - & - & - & - & - & - & - & - \\
\hline Rhaphoneis amphiceros -.-- & - & - & - & - & + & - & - & + & - & $R$ & $\mathrm{R}$ & $R$ & $R$ & + & R & $\mathrm{R}$ & + & + & - & - & - & P. & - & + \\
\hline Rhaphoneis miocenica - & - & - & - & - & - & - & - & - & - & R & - & R & - & - & + & - & + & + & - & - & - & R & + & $R$ \\
\hline Rhaphoneis parilis - - & - & - & - & - & - & - & - & - & - & - & - & - & - & - & - & - & - & - & - & - & + & - & + & R \\
\hline Rhizosolenia styliformis - & + & + & $R$ & - & + & + & - & - & + & - & R & - & - & + & + & + & + & + & - & + & + & + & - & - \\
\hline Rouxia diploneides & - & - & - & - & - & - & - & - & - & - & - & - & - & - & - & - & - & - & - & R & - & R & + & R \\
\hline Rouxia naviculoides & $\mathrm{F}$ & R & $\mathrm{R}$ & - & + & - & - & + & - & R & R & + & - & + & + & R & - & - & - & + & - & $R$ & + & R \\
\hline Stephanogonia polyacantha. & + & - & - & - & + & - & + & + & - & - & - & + & + & R & - & + & - & + & + & + & + & + & + & - \\
\hline Stephanopyxis schenckii & f & E & $\mathrm{E}$ & - & - & - & - & + & + & + & + & + & + & + & + & R & $\mathrm{R}$ & $\mathrm{R}$ & + & + & - & R & + & + \\
\hline Stephanopyxis $t$ & R & + & $\mathrm{F}$ & - & R & - & - & + & + & + & $\mathrm{R}$ & + & R & $R$ & - & - & $\mathrm{R}$ & R & R & + & - & + & + & + \\
\hline Stictodiscus californicus - & + & - & - & - & + & + & - & - & - & - & - & - & - & + & - & - & + & + & - & + & - & - & + & - \\
\hline Syndendrium di adema - & - & - & - & - & - & - & - & - & + & - & - & + & + & - & - & - & - & - & + & - & - & + & + & + \\
\hline Synedra jouseana --......... & + & - & R & $\mathrm{R}$ & c & c & A & $c$ & A & $\mathrm{F}$ & c & A & A & A & c & c & $c$ & $c$ & c & A & + & $\mathrm{F}$ & $\mathrm{R}$ & $R$ \\
\hline Thalassionema nitzschioides & $R$ & $\mathrm{~F}$ & C & + & $\mathrm{F}$ & $\mathrm{c}$ & $\mathrm{c}$ & A & A & A & $\mathrm{F}$ & $\mathrm{F}$ & $\mathrm{F}$ & $\mathrm{F}$ & $\mathrm{F}$ & c & c & A & $c$ & c & A & $\mathrm{F}$ & $c$ & A \\
\hline Thalassiosira leptopus & R & - & + & - & + & - & - & - & + & - & + & - & - & - & - & - & + & - & + & + & + & + & + & + \\
\hline ira sp. 1 & + & - & - & - & + & - & - & + & + & - & - & - & - & - & - & - & - & + & + & - & - & - & - & \\
\hline Thalassiothrix longissima & R & R & $\mathrm{F}$ & + & $\mathrm{F}$ & $R$ & $\mathrm{R}$ & $R$ & $\mathrm{~F}$ & $\mathrm{~F}$ & R & $\mathrm{F}$ & $\mathrm{F}$ & $\mathrm{F}$ & R & R & $\mathrm{F}$ & c & $\mathrm{F}$ & $\mathrm{F}$ & $\mathrm{F}$ & $\mathrm{F}$ & $\mathrm{F}$ & $\mathrm{F}$ \\
\hline Im condecorum & + & - & - & - & + & - & - & + & + & + & - & - & - & - & - & + & + & + & - & - & - & + & + & $\mathrm{R}$ \\
\hline Xanthiopyxis globos - & + & - & - & + & + & + & - & - & + & - & + & + & - & - & + & + & - & + & + & - & - & + & + & + \\
\hline Xanthiopyxis maculata - & - & - & - & - & - & - & - & - & + & - & - & + & + & - & - & - & + & - & - & + & - & - & + & + \\
\hline nthiopyxis ovalis & + & - & - & - & + & - & - & + & - & - & - & + & + & + & + & + & - & + & + & + & - & + & + & - \\
\hline
\end{tabular}

southern California. Data on boundaries from measured sections, however, are sparse, and assessment of the chronostratigraphic value of benthic foraminiferal correlations of the Luisian Stage awaits future study.

\section{Paleoecology}

The type Luisian diatom assemblage is composed primarily of planktic taxa (text-fig. 4). The benthic-tychopelagic component is seldom as great as $20 \%$ of the assemblage, although it increases dramatically to a maximum of $36 \%$ at the top of the section. Resting spore abundances are typically less than $5 \%$, and peaks parallel those of the benthic-tychopelagic taxa. Benthic foraminiferal studies (McDougall, oral communication, 1980) suggest that many of these fluctuations may be due to downslope transport. Sample L24 in the Hames Member of the Monterey Formation is about $23 \mathrm{~m}$ stratigraphically below the base of the Santa Margarita Formation, and the basal Santa Margarita is a shoreline to shallow subtidal deposit according to Addicott (in Addicott et al., 1978), therefore, the relatively abundant and diverse benthic and tychopelagic taxa in L24 (table 1) may reflect a shoaling of the section.

Among the planktic diatoms, nine taxa account for approximately $75 \%$ of the assemblage throughout the section. These taxa include three species of Denticulopsis [D. lauta (Bailey) Simonsen, D. hustedtii, and $D$. hyalina], three different varieties of Actinocyclus ingens ( $A$. ingens s. ampl., $A$. ingens s. str., and $A$. ingens var. nodus Baldauf), Synedra jouseana, Thalassionema nitzschoides Grunow, and Thalassiothrix longissima (text-fig. 5). 


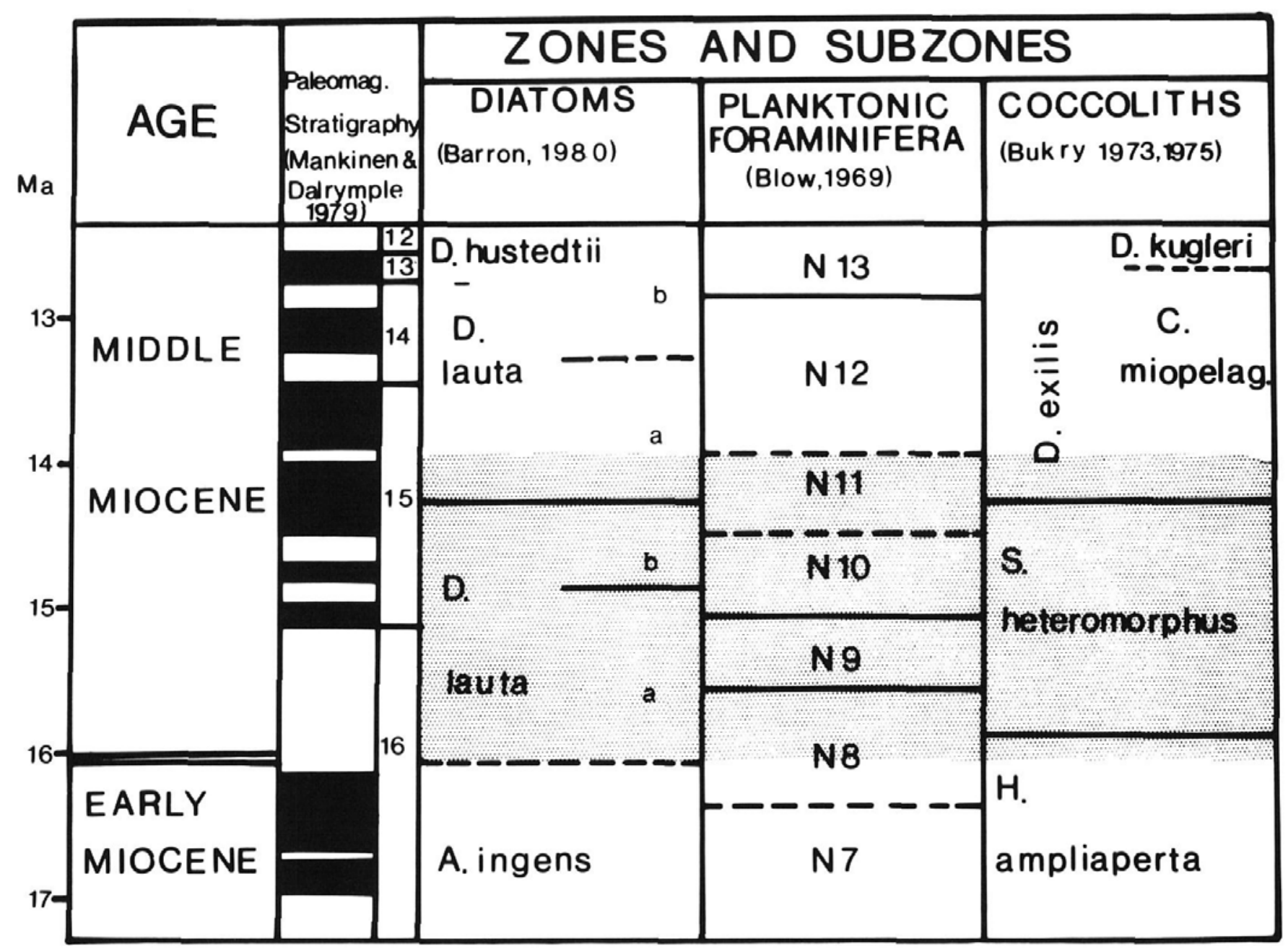

TEXT-FIGURE 3

Diatom correlation of type Luisian Stage to geologic time scale. Time scale of Yeats, Haq et al. (1981).

The Denticulopsis group represents a cold-water component, because these species are consistently more common at the more northern latitudes of the Pacific during the Miocene, and because $D$. seminae Simonsen and Kanaya (1961), the modern representative, is a northern boreal species (Kanaya and Koizumi, 1966; Jousé et al., 1971). During the late Middle Miocene, $D$. hustedtii is introduced into the tropics. This introduction coincides with major climatic cooling recorded by Kennett (1977), Woodruff et al. (1979) and Crouch and Bukry (1979).

The Actinocyclus ingens group represents a more temperate component. Actinocyclus ingens appears to be more common in the middle latitudes of the North Pacific during the Middle Miocene, and it is introduced into the tropics prior to the introduction of $D$. hustedtii, probably closer to the initiation of the
Middle Miocene cooling trend (Barron, unpublished data, DSDP Site 77).

Synedra jouseana is a consistent component of Early Miocene and early Middle Miocene assemblages from the tropical Pacific (Jousé, 1974; Gombos, 1975; Schrader, 1978). Although S. jouseana is also a common constituent of early Middle Miocene diatom assemblages from middle to high latitudes of the North Pacific (Burckle, 1978), it declines in abundance in the late Middle Miocene (Schrader, 1973; Barron, 1976, 1981), presumably in response to climatic cooling. Consequently, for purposes of this study $S$. jouseana is considered to represent a warm-water component. This conclusion is supported by $S$. jouseana's inverse relationship with respect to Denticulopsis spp., a cold-water group, in text-figure 5 . 


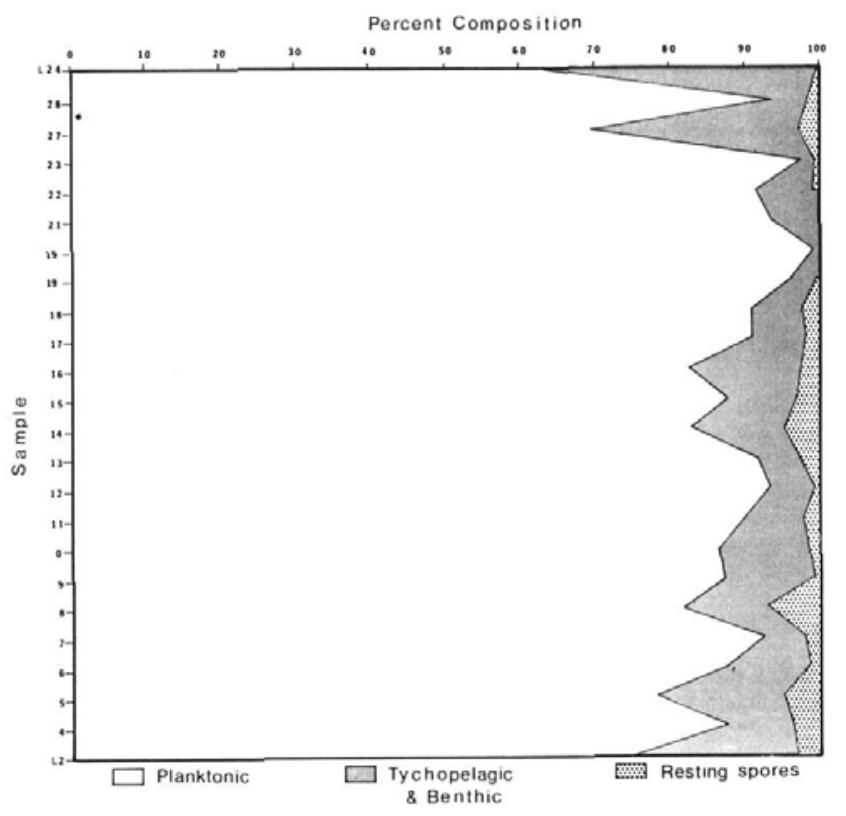

TEXT-FIGURE 4

Percentage fluctuation of planktic diatoms, benthic and tychopelagic diatoms, and resting spores in samples studied from type Luisian (samples L2-L27) and overlying rocks (L28 and L24).

Adoption of this model suggests cool to temperate conditions at the base of the section, followed upsection by a warming trend beginning with sample $\mathrm{L} 7$ and culminating in sample L14. A cooling trend followed with some incorporated fluctuation and with pronounced intensification at about sample L27 at the top of the type Luisian Stage.

It is necessary to determine whether these temperature trends are applicable over a broad area or merely represent local basin conditions reflecting coastal configuration. For example, Middle Miocene diatom assemblages from Upper Newport Bay (Barron, 1976) generally possess less of a warm-water component than equivalent assemblages from offshore southern California (Barron, 1981), implying an offshore to onshore temperature gradient. Trends in equivalent sections in California should be compared to this study, and completion of studies of the type Luisian benthic foraminifers, planktic foraminifers, and coccoliths (Poore et al., 1981) will allow direct comparison within the area.

The widespread nature of the cooling in the upper part of the type Luisian section is, however, supported by other data. At DSDP Site 289 in the western equatorial Pacific, Woodruff et al. (1979) recorded a steady positive increase in the $\delta \mathrm{O}^{18}$ of benthic foraminifers beginning in the lower part of planktic foraminiferal Zone $\mathrm{N} 9$ and continuing through Zone N12 (compare text- fig. 3), which we attribute to rapid growth of the Antarctic icecap. Earlier oxygen isotope studies by Shackleton and Kennett (1975) on DSDP sites off New Zealand also strongly support this cooling trend. Associated high-latitude cooling would certainly cause intensification of the cool-water California Current and resultant assemblage changes. Cooling at the top of the Luisian Stage in California is recorded by mollusks (Addicott, 1970), benthic foraminifers (Kleinpell, 1938), planktic foraminifers (Ingle, 1973), and coccoliths (Crouch and Bukry, 1979) and is supported by the increased siliceous character of overlying rocks.

\section{CONCLUSIONS}

1. One hundred four diatom taxa typical of the early Middle Miocene of California are reported from the type section of Kleinpell's (1938) Luisian Stage. One new species, Coscinodiscus volutus Baldauf, is proposed.

2. The type Luisian section ranges from the lowermost part of the Denticulopsis lauta Zone to the lower part of the Denticulopsis hustedtii-D. lauta Zone. The type Luisian section is early Middle Miocene in age and ranges from about 16.0 to $14.0 \mathrm{Ma}$.

3. Planktic diatoms average $80 \%$ of the assemblage. Fluctuations in benthic and tychopelagic diatoms are interpreted to be due to downslope transport, with the exception of probable shoaling at the top of the section.

4. Interpreted climatic cooling in the upper part of the section is supported by both megafossils and microfossils and corresponds to similar events in the Pacific as shown by oxygen isotope studies.

\section{APPENDIX}

Description of a new species

Genus COSCINODISCUS Ehrenberg

Coscinodiscus volutus Baldauf, n. sp.

Plate 2 , figures $1-4$; plate 3 , figure 2

Description: Valve circular, 35 to $85 \mu \mathrm{m}$ in diameter, center slightly depressed, possessing distinct nodule. Areolae round, 6-7 in $10 \mu \mathrm{m}$ in size, from near center to approximately three-fifths of radius where they increase slightly in size (5 in $10 \mu \mathrm{m})$ toward margin. Areolae radially arranged, exhibiting slight fasciculation; pronounced secondary spiral present. Center of areolae pattern displaced from center of valve. Margin indistinct but possessing, at intervals of $10-15 \mu \mathrm{m}$, tabular hyaline areas 1-2 $\mu \mathrm{m}$ square (see pl. 2, fig. 2). Submarginal labiate processes $1 \mu \mathrm{m}$ in length on underside, at intervals of $10 \mu \mathrm{m}$ (see pl. 2, fig. 3).

Remarks: The absence of a central subcircular cluster of areolae surrounded by a hyaline band, the presence 
TEM PERATE

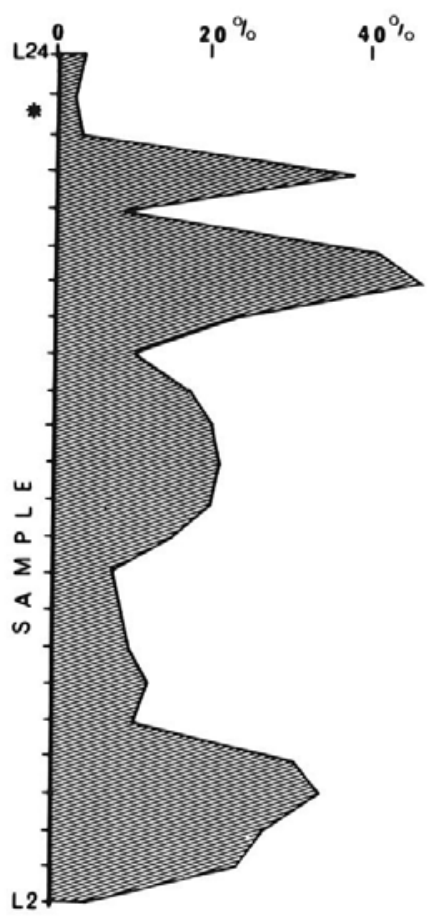

A. ingens vars.
WARM

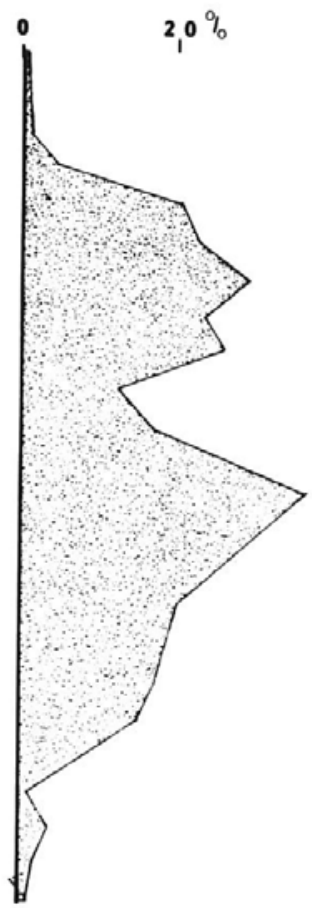

S. jouseana
COLD

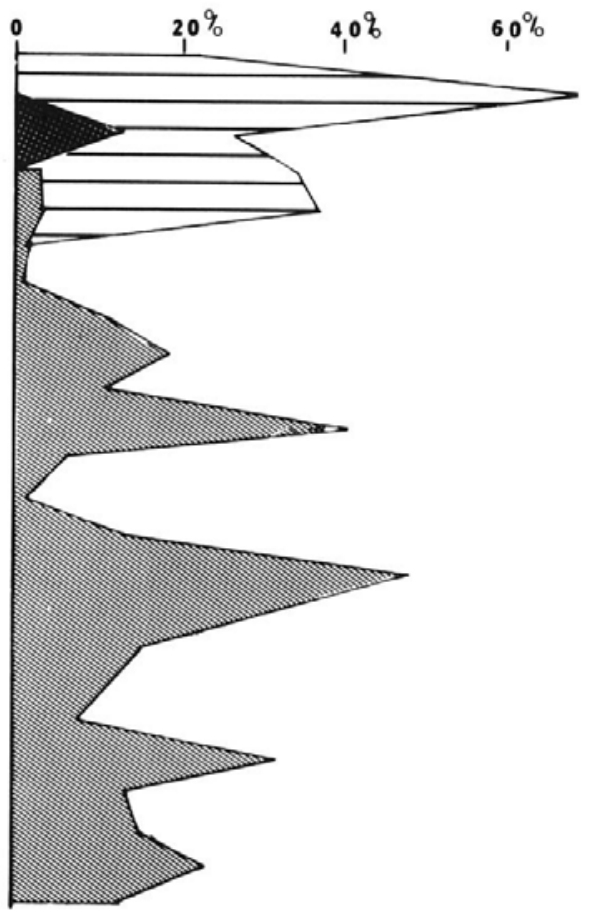

D. hustedtii

目 D. hyalina

D. lauta

\section{OTHER}

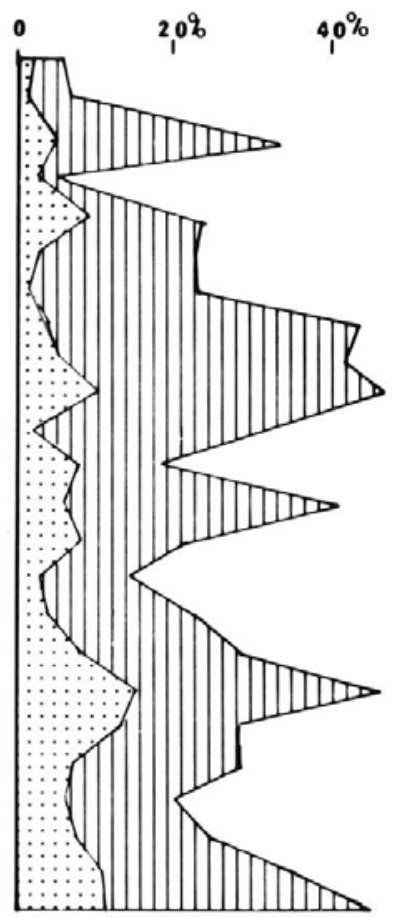

III T. nit zschoides

T. longissima

TEXT-FIGURE 5

Percentage fluctuation of Actinocyclus ingens (vars.), Synedra jouseana, Denticulopsis spp. (D. hustedtii, D. hyalina, and D. lauta), and other taxa in samples studied from type Luisian. These are interpreted as temperate-, warm-, and cold-water components (see text).

of a secondary spiral, and the offset of the areolae pattern from the center of the valve, distinguish Coscinodiscus volutus from Coscinodiscus vetustissimus Pantocsek.

Coscinodiscus tabularis Grunow is easily separated from $C$. volutus by the presence of a marginal hyaline band, the absence of a secondary spiral, and the size of the areolae, which are 3-4 in $10 \mu \mathrm{m}$ in C. tabularis compared to $6-7$ in $10 \mu \mathrm{m}$ in $C$. volutus.

Distribution: Coscinodiscus volutus occurs throughout the Middle Miocene Denticulopsis lauta and the lower part of the Denticulopsis hustedtii-D. lauta zones of Barron (1980) in the type Luisian area. Further studies to determine the stratigraphic as well as geographic limits of this taxon need to be conducted.

Holotype: Plate 3, figure 2, USNM 311178.

Isotypes: Plate 2, figures 1-4, USNM 311179 and 311180.

Type locality: Sample L10; the Sandholt Member of the Monterey Formation; type Luisian section of Kleinpell (1938); SE $1 / 4$ of section 21 of the Wilson Corner $71 / 2$-minute quadrangle, California.

\section{TAXONOMIC NOTES}

No effort was made to separate individual species of Cestodiscus or varieties of Actinocyclus ehrenbergii Ralfs.

Actinocyclus cholnokyi Van Landingham, 1967, p. 83; Koizumi, 1968, p. 207. Synonym: Actinocyclus divisus Kisselev, 1931, p. 113, pl. 1, fig. 1.

Actinocyclus ehrenbergii Ralfs in Pritchard, 1861, p. 834; Hustedt, 1929, p. 525, fig. 298; Schrader, 1973, p. 701, pl. 19, fig. 1. Remarks: Many varieties of this species were observed. This taxon should be revised, but that is not the purpose of the present paper. [Plate 1, figure 5]

Actinocyclus ehrenbergii var. ralfsii (Wm. Smith) Hustedt, 1929. p. 528, fig. 299; Cleve-Euler, 1951, p. 82, fig. 144b. Synonym: Eupodiscus ralfsii Wm. Smith, 1856, p. 86.

Actinocyclus ehrenbergii var. tenella (Brébisson) Hustedt, 1929, p. 530 , fig. 302; Kanaya, 1959, p. 95, pl. 7, figs. 2, 3. [Plate 1. figure 7] 
Actinocyclus ingens Rattray, $1890 \mathrm{~b}, \mathrm{~s}$ str. (undulated), p. 149, pl. 11, fig. 7. Synonym: Actinocyclus ingens Rattray: Sheshukova-Poretzkaya, 1967, pl. 30, fig. 1; Actinocyclus ingens var. 1 Barron, 1980.

Description: Valve circular, observed specimens 10 to $65 \mu \mathrm{m}$ in diameter. Valve surface slightly undulated increasing from center to highest point at approximately one-third of radius, decreasing to margin. At highest point valve surface exhibiting distinct submarginal ring. Areolae subrounded, arranged in radial rows. Primary rows extending length of radius; several shorter secondary rows between two primary rows. Radial rows separated from one another by hyaline areas. Areolae increasing from 5 in $10 \mu \mathrm{m}$ in central region to 4 in $10 \mu \mathrm{m}$ at highest point; then decreasing from 6 in $10 \mu \mathrm{m}$ toward margin, where 8 in $10 \mu \mathrm{m}$ were observed.

Remarks: Actinocyclus ingens Rattray is characterized by having an undulating valve surface, and a depressed center. Rattray's (1890b) type description notes, "surface rising gradually from the center to about $2 / 5$ of the radius to the highest zone; this zone slightly convex, its outer edge sloping down to the border so as to form a distinct submarginal band." Although a wide morphological variation has been observed by past workers, only specimens strictly fitting the definition were tabulated as Actinocyclus ingens s. str. (undulated). The other flatter varieties that were referred to as Actinocyclus ingens by past workers are tabulated as Actinocyclus ingens s. ampl. [Plate 1, figure 8]

Actinocyclus ingens Rattray, 1890b, s. ampl. (flat), p. 149; Koizumi, 1973 , p. 831 , pl. 1, figs. 13, 14; pl. 2, figs. 1, 2. Synonym: Actinocyclus tsugaruensis Kanaya, 1959, p. 99, pl. 8, figs. 5-8. Remarks: This form of Actinocyclus ingens differs from A. ingens s. str. by having a flat valve surface, and no raised submarginal ring of any kind. [Plate 1, figures 6,10$]$

Actinocyclus ingens var. nodus Baldauf in Baldauf and Barron, 1980, p. 104, pl. 1, figs. 5-9. Synonym: Actinocyclus ingens Rattray: Jousé, 1977, pl. 53, fig. 1.

Description: Valve circular, 35 to $65 \mu \mathrm{m}$ in diameter. Valve concentrically undulated, with raised central and submarginal ring areas separated by continuous depression. Central area appearing as areolated node covering approximately one-fifth of diameter. Width of adjacent depression varying between specimens. Submarginal raised ring distinct and same height as central area. Areolae subrounded and arranged in radially lineate rows. Primary rows extending length of radius, secondary rows from depression region to margin. Areolae larger (5 in $10 \mu \mathrm{m}$ ) in central and submarginal zones and surrounded in hyaline areas. Areolae decreasing in size (9 in $10 \mu \mathrm{m}$ ) in the submarginal area, where they are indistinctly separated by hyaline areas. Pseudonodule near margin similar to that of Actinocyclus ingens Rattray, where it is de- scribed as obscure, sharply angular, with irregular edges.

Remarks: Actinocyclus ingens var. nodus Baldauf differs from Actinocyclus ingens Rattray var. ingens by the presence of a raised central area, which is equal in height to the raised submarginal ring. Rattray's type concept of Actinocyclus ingens includes specimens with depressed center and raised submarginal rings. [Plate 1, figure 9]

Actinoptychus splendens var. halionyx Grunow in Van Heurck, 1883, pl. 119, fig. 3; pl. 120, fig. 3; Hustedt, 1929, p. 478, fig. 265. [Plate 1, figure 1]

Actinoptychus thumii (Schmidt) Hanna, 1932, p. 171, pl. 4, figs. 3, 4. Synonym: Actinoptychus stellaris var. thumii Schmidt in Schmidt et al., 1886, pl. 90, fig. 3; pl. 100, fig. 6. [Plate 1, figure 3]

Actinoptychus undulatus (Bailey) Ralfs in Pritchard, 1861, p. 839, pl. 5, fig. 88; Hustedt, 1929, p. 475, fig. 264. Synonym: Actinocyclus undulatus Bailey, 1842, pl. 2, fig. 11. [Plate 1, figure 4]

Actinoptychus vulgaris var. monicae Grunow in Van Heurck, 1883, pl. 121, fig. 9; Wornardt, 1967, p. 51, figs. 79-81; Barron, 1975, p. 121, pl. 2, fig. 11. [Plate 1, figure 2]

Annellus californicus var. hannai Barron, 1981, pl. 6, figs. 3, 4, 6, 9-12; pl. 7, figs. 1-3. Synonym: Annellus californicus Tempère: Hanna, 1932, pl. 4, figs. 5-7 (not 8). [Plate 5, figures 4, 6]

Arachnoidiscus ornatus var. montereyanus Schmidt, 1882, pl. 73, figs. 8, 9; Wornardt, 1967, p. 40, figs. 62, 63. [Plate 6, figure 5]

Asteromphalus flabellatus (Brébisson) Greville, 1859a, p. 161, pl. 7, fig. 6; Lohman, 1974, p. 346, pl. 4, fig. 2. Synonym: Spatangidium flabellatum Brêbisson, 1857, p. 297, pl. 3, fig. 3.

Asteromphalus robusta Castracane, 1875, p. 393, pl. 6, fig. 5; Hustedt, 1929, p. 496, fig. 278.

Aulacodiscus concentricus (Mann) Boyer, 1926, p. 76; Wornardt, 1967, p. 52, fig. 83. Synonym: Tripodiscus concentricus Mann, 1907 , p. 279 , pl. 54 , fig. 4.

Aulacodiscus kittoni Arnott ex Ralfs in Pritchard, 1861, p. 844, pl. 8, fig. 24; Hustedt, 1929, p. 506, fig. 283; Hendey, 1964, p. 98, pl. 22, fig. 5. [Plate 6, figure 6]

Biddulphia aurita (Lyngbye) Brébisson et Godey, 1838, p. 12; Hustedt, 1930, p. 846, fig. 501; Schrader, 1973, p. 702, pl. 13, figs. $1-$ 3. Synonym: Diatoma auritiium Lyngbye, 1819, pl. 52, fig. D.

Biddulphia tuomeyi (Bailey) Roper, 1859, p. 8, pl. 1, figs. 1, 2; Hustedt, 1930, p. 834, fig. 491; Lohman, 1974, p. 347, pl. 5, fig. 3. Synonym: Zygoceros tuomeyi Bailey, 1844, p. 138, pl. 3, figs. 3, 4. [Plate 6, figure 2]

Campyloneis grevillei (Wm. Smith) Grunow, 1870, p. 11; Van Heurck, 1896, p. 285, fig. 64; Hustedt, 1933, p. 321, fig. 781. Synonym: Cocconeis grevillei Wm. Smith, 1853, p. 22, pl. 3, fig. 35.

Cestodiscus sp.-Genus Cestodiscus Greville, 1865, pp. 13, 48, pl. 5, figs. 8, 9; Grunow in Van Heurck, 1883, pl. 126; Lohman, 1974, p. 339. Remarks: This genus is rare throughout the section. Specific identification of individual specimens was not attempted.

Chaetoceros cinctus Gran, 1897, p. 24, pl. 2, figs. 23-27; Hustedt, 1930, p. 748, fig. 432; Wornardt, 1967, p. 69, fig. 135.

Chaetoceros dicladia Castracane, 1886, p. 82, pl. 8, fig. 1; pl. 19, figs. 7, 8; Karsten, 1905, p. 119, pl. 16, fig. 2; Kanaya, 1959, p. 117. 
pl. 11, figs. 1, 2. Synonym: Dicladia pylea Hanna and Grant, 1926, p. 142 , pl. 16, figs. $4,5$.

Cladogramma dubium Lohman, 1948, p. 168, pl. 9, fig. 5; Schrader, 1973, p. 702, pl. 13, figs. 17, 18, 21; pl. 24, fig. 11a; Barron, 1975 , p. 128 , pl. 5 , fig. 10.

Cocconeis costata Gregory, 1855, p. 39, pl. 4, fig. 10; Hustedt, 1933, p. 332, fig. 785; Sheshukova-Poretzkaya, 1967, p. 44, fig. 4.

Cocconeis dirupta var. triumphis (Hanna and Grant) Frenguelli, 1949 , p. 111, pl. 6, fig. 9. Synonym: Cocconeis triumphis Hanna and Grant, 1926, p. 135, pl. 14, figs. 11-13; Wornardt, 1967, p. 80 , fig. 182.

Cocconeis distans Gregory, 1857, p. 490, pl. 1, fig. 23; Hustedt, 1933, p. 343, fig. 797; Barron, 1975, p. 130, pl. 5, fig. 16.

Cocconeis scutellum Ehrenberg, 1838, p. 194, pl. 14, fig. 8; Hustedt, 1933, p. 338, fig. 790; Barron, 1975, p. 130, pl. 5, fig. 19. [Plate 6, figure 1]

Cocconeis vitrea Brun, 1891, p. 19, pl. 18, fig. 2; Kanaya, 1959, p. 110, fig. 6; Wornardt, 1967, p. 81, figs. 183-184.

Coscinodiscus asteromphalus Ehrenberg, 1844, p. 77; 1854, pl. 18, fig. 45; pl. 33, figs. 7, 15; Hustedt, 1928, p. 452, fig. 250; Wornardt, 1967, p. 20, figs. 14-18; Barron, 1975, p. 132, pl. 6. fig. 3.

Coscinodiscus gigas var. diorama (Schmidt) Grunow, 1884, p. 76; Rattray, 1890, p. 542, fig. 94; Barron, 1975, p. 133, pl. 6, fig. 11. Synonym: Coscinodiscus diorama Schmidt in Schmidt et al., 18741959, pl. 64, fig. 2

Coscinodiscus lewisianus Greville, 1866, p. 78, pl. 8, figs. 8-10: Reinhold, 1937, p. 96, pl. 8, fig. 11; Schrader, 1973, p. 703, pl. 8, figs. 1-6, 10, 15.

Coscinodiscus marginatus Ehrenberg, 1841a, p. 142; 1854, pl. 18, fig. 44; Hustedt, 1928, p. 416, fig. 223; Hanna, 1932, p. 181, pl. 8 , figs. 4, 5. Remarks: Two forms of this species were observed. Form 1 contains large central areolae (5 in $10 \mu \mathrm{m})$ which decrease in size toward the coarsely striated $(8$ in $10 \mu \mathrm{m})$ margin and has a valve surface that is greatly convex. Form 2 has a valve surface that is less convex, the central areolae are 7 in $10 \mu \mathrm{m}$ and decrease toward the finely striated margin (12 in $10 \mu \mathrm{m}$ ). Both forms have diameters from 25 to $85 \mu \mathrm{m}$. [Plate 5 , figures $2-3,7$ ]

Coscinodiscus nitidus Gregory, 1857, p. 499, fig. 45; Hustedt, 1928 , p. 414, figs. 30, 31; Wornardt, 1967, p. 27, figs. 30, 31; Barron, 1975, p. 134, pl. 7, fig. 3.

Coscinodiscus obscurus Schmidt, 1878, in Schmidt et al., 18741959, pl. 61, fig. 16; Rattray, 1890, p. 513, fig. 65; Hustedt, 1928, p. 418, pl. 224; Wornardt, 1967, p. 27, fig. 32. [Plate 3, figure 1]

Coscinodiscus oculus-iridis Ehrenberg, 1839, p. 147; 1854, pl. 18, fig. 42; pl. 19, fig. 2; Hanna, 1932, p. 183, pl. 9, fig. 4; Barron, 1975, p. 135, pl. 7, fig. 9. [Plate 5, figure 1]

Coscinodiscus plicatus Grunow, 1878 in Schmidt et al., 18741959, pl. 59, fig. 1; Grunow, 1884, p. 73, pl. 3c, fig. 10; Schrader, 1973, p. 703, pl. 6, fig. 23.

Coscinodiscus praeyabei Schrader, 1973, pl. 6, fig. 16; pl. 7, figs. 17-20, 22, 23. [Plate 3, figure 4]

Coscinodiscus salisburyanus Lohman, 1948, p. 164, pl. 7, fig. 5; 1974, p. 337, pl. 2, figs. 5, 7.

Description: Valve circular, flat, 25-60 $\mu \mathrm{m}$ in diameter. Irregular central area occupied by obscure nodule and rounded to subrounded granules. Areolae hexagonal
(7 in $10 \mu \mathrm{m})$ near center, increasing $\left(5 \frac{1}{2}\right.$ in $\left.10 \mu \mathrm{m}\right)$ at one-half radius, then decreasing (6 in $10 \mu \mathrm{m})$ near margin. Areolae radially arranged with fasciculated to subfasciculated pattern. Longest rows extending length of radius and parallel with radius. Margin narrow, finely striated (12 in $10 \mu \mathrm{m}$ ).

Remarks: Lohman (1974) stated, "2-4 irregularly rounded granules occupy the central space." Specimens observed contain two or no granules. The small specimens were difficult to distinguish from Coscinodiscus nodulifer because their fasciculated areolar pattern is not well developed. [Plate 4, figure 4]

Coscinodiscus symbolophorus Grunow, 1884, p. 86; Rattray, 1890a, p. 583, fig. 135; Hustedt, 1928, p. 427, fig. 230. [Plate 4, figure 1]

Coscinodiscus tabularis Grunow, 1884, p. 86; Rattray, 1890a, p. 583, fig. 135; Hustedt, 1928, p. 427, fig. 230.

Description: Valve circular, 15-60 $\mu \mathrm{m}$ in diameter. One distinct nodule present near center. Areolae round, 3-4 in $10 \mu \mathrm{m}$ throughout, radius decreasing slightly at margin. Areolae radially arranged, showing fasciculated pattern. Margin finely areolated (8 in 10 $\mu \mathrm{m})$ with distinct apiculi present every $10 \mu \mathrm{m}$. Distinct hyaline band separating apiculi and margin from rest of valve.

Remarks: Hustedt (1959) and Fenner (1978) described a wide morphological variation in Coscinodiscus tabularis, which includes specimens matching Coscinodiscus endoi Kanaya. In this paper all specimens of Coscinodiscus endoi are tabulated as Coscinodiscus tabularis. [Plate 4, figures 6-7]

Coscinodiscus tuberculatus Greville, 1861, p. 42, pl. 4, fig. 6; Grunow, 1888, p. 30, pl. 3, fig. 29; Rattray, 1890a, p. 482; Kolbe, 1954 , p. 35, pl. 1, fig. 11. [Plate 4, figures 3, 5, 8]

Coscinodiscus vetustissimus Pantocsek, 1886, p. 71, pl. 20, fig. 186; Rattray, 1890a, p. 477, fig. 29; Hustedt, 1928, p. 412, fig. 210; Andrews, 1976, p. 12, pl. 3, fig. 3.

Description: Valve circular, observed specimens ranging from 52 to $87 \mu \mathrm{m}$ in diameter. Central region slightly depressed containing distinct variably shaped nodule, also distinct, irregular to subcircular cluster of areolae. Cluster approximately 6-9 $\mu \mathrm{m}$ broad, and surrounded by narrow hyaline band. Areolae hexagonal increasing slightly from center (6 in $10 \mu \mathrm{m})$ to radius (5 in $10 \mu \mathrm{m}$ ), then decreasing to margin (7 in $10 \mu \mathrm{m}$ ). Areolae arranged in radial rows, with fasciculated pattern. Longest radial rows extending from center to margin and parallel to edge. Margin narrow and finely striated (18 in $10 \mu \mathrm{m}$ ).

Remarks: Coscinodiscus vetustissimus can be readily distinguished from other Coscinodiscus species by its irregular central cluster of areolae, which is surrounded by a distinct hyaline band. [Plate 3, figures 5-7] 
Craspedodiscus coscinodiscus Ehrenberg, 1844b, p. 266; 1854 , pl. 18, fig. 108; Rattray, 1890a, p. 600; Kolbe, 1954, p. 36, pl. 1, fig. 4; Kanaya, 1971, p. 555, pl. 40.4, figs. 1-3.

Craspedodiscus rhombicus Grunow, 1881 in Schmidt et al., 18741959, pl. 61, fig. 13; Wornardt, 1967, p. 33, figs. 44, 45; Barron, 1975, p. 137, pl. 8, figs. 1, 2.

Cussia paleacea (Grunow) Schrader, 1974, p. 543, pl. 1, figs. 1114. Synonym: Stoschia paleacea Grunow in Van Heurck, 1883, pl. 128, fig. 6 .

Cymatogonia amblyoceras (Ehrenberg) Hanna, 1932, p. 186, pl. 10, fig. 5; Schrader, 1973, p. 704, pl. 26, fig. 8. Synonym: Triceratium amblyocera Ehrenberg, 1844, p. 88; 1854, pl. 18, fig. 51.

Delphineis angustata (Pantocsek) Andrews, 1977, pp. 250-251, pl. 1, figs. $1-4$; pl. 2, figs. 21-22; pl. 3, figs. 29-30; Abbott and Andrews, 1979, p. 242, pl. 4, fig. 1. Synonym: Rhaphoneis angustata Pantocsek, 1886, pt. 1, p. 33, pl. 11, fig. 97; pl. 30, fig. 313; Lohman, 1948, p. 180, pl. 11, fig. 11; Andrews, 1976, p. 20, pl. 7. figs. 1, 2. [Plate 7, figures 17-18]

Delphineis penelliptica Andrews, 1977, p. 253, pl. 1, figs. 16-20; pl. 2, figs. 27, 28; pl. 4, figs. 35, 36 .

Denticulopsis hustedtii (Simonsen and Kanaya) Simonsen, 1979, p. 64. Synonym: Denticula hustedtii Simonsen and Kanaya, 1961, p. 501, pl. 1, figs. 19-25; pl. 2, figs. 36-47; Schrader, 1973, p. 704 , pl. 2 , figs. $28-34,36-47$. [Plate 7 , figures 7,8 ]

Denticulopsis hyalina (Schrader) Simonsen, 1979, p. 64. Synonym: Denticulina hyalina Schrader, 1973, p. 704, pl. 1, figs. 12-22. [Plate 7, figures 2, 4]

Denticulopsis lauta (Bailey) Simonsen, 1979, p. 64. Synonym: Denticula lauta Bailey, 1854, p. 9, figs. 1, 2. [Plate 7, figure 5]

Denticulopsis nicobarica (Grunow) Simonsen, 1979, p. 65. Synonym: Denticula nicobarica Grunow, 1868, pl. 19, fig. 5. [Plate 7, figure 6]

Denticulopsis punctata (Schrader) Simonsen, 1979, p. 65. Synonym: Denticula punctata Schrader, 1973, p. 705, pl. 1, figs. 25-30; pl. 3; figs. 16, 17. [Plate 7, figure 7]
Diploneis interrupta (Kützing) Cleve, 1894, p. 84; Hustedt, 1937, p. 604 , fig. 1019; Barron, 1975, p. 140, pl. 8, fig. 15. Synonym: Navicula interrupta Kützing, 1844, p. 100, pl. 29, fig. 93.

Diploneis smithii (Brébisson) Cleve, 1894, p. 96; Hustedt, 1937. p. 647 , fig. 1051; Barron, 1975, p. 140, pl. 8, fig. 17. Synonym: Navicula smithii Brébisson in Wm. Smith, 1856, p. 92.

Dossetia lacera (Forti) Hanna, 1932, p. 190, pl. 11, fig. 3; Wornardt, 1967, p. 72, figs. 144, 145; Barron, 1975, p. 140, pl. 8, fig. 23. Synonym: Xanthiopyxis lacera Forti in Tempère and Peragallo, 1910, p. 197.

Entopyla australis var. gigantea (Greville) Fricke, 1902 in Schmidt et al., 1874-1959, pl. 230, figs. 1-11; Wornardt, 1967, p. 80, figs. 177-180; Barron, 1975, p. 131, pl. 8, fig. 24. Synonym: Gephyria gigantea Greville, 1866, p. 122, pl. 11, figs. 7, 8. [Plate 7, figure 14]

Glyphodiscus stellatus Greville, 1862, p. 91, pl. 9, fig. 5; Wornardt, 1967, p. 58, fig. 120a; Schrader, 1973, p. 705, pl. 22, fig. 6.

Goniothecium rogersii Ehrenberg, 1841b, p. 406; 1854, pl. 18, figs. 92-93; Karsten, 1928, p. 301, fig. 419b; Hanna, 1932, p. 192 pl. 11, figs. 4-6.

Grammatophora angulosa Ehrenberg, 1839, p. 153; 1841b, pl. 1, fig. 3; Hustedt, 1931, p. 39, fig. 564; Barron, 1975, p. 142, pl. 9, fig. 10.

Grammatophora merletta Hanna and Grant, 1926, p. 146, pl. 16, figs. 11, 12, 14; Lohman, 1974, p. 354, pl. 6, fig. 3; Barron, 1975 , p. 143 , pl. 9, fig. 11.

Hemiaulus polymorphus Grunow, 1884, p. 66; Hustedt, 1930, p. 880; Hanna, 1932, p. 193, pl. 11, fig. 7; Lohman, 1974, p. 349, pl. 5, fig. 6 .

Hyalodiscus radiatus (O'Meara) Grunow in Cleve and Grunow, 1880, p. 117; Grunow, 1884, p. 93; Hustedt, 1928, p. 195, fig. 135. Synonym: Pyxidicula radiata O'Meara, 1877, p. 58, pl. 1, fig. 9. [Plate 6, figure 3]

Liradiscus bipolaris Lohman, 1948, p. 165, pl. 8, fig. 5; 1974, p. 346, pl. 4, fig. 11.
1 Actinoptychus splendens var. halionyx Grunow Sample L7, diameter $152 \mu \mathrm{m}$.

2 Actinoptychus vulgaris var. monicae Grunow Sample L5, diameter $147 \mu \mathrm{m}$.

3 Actinoptychus thumii (Schmidt) Hanna Sample L9, diameter $22 \mu \mathrm{m}$.

4 Actinoptychus undulatus (Bailey) Ralfs Sample L8, diameter $34 \mu \mathrm{m}$.

5 Actinocyclus ehrenbergii Ralfs Sample L10, diameter $28 \mu \mathrm{m}$.
6 Actinocyclus ingens Rattray s. ampl. (flat) Sample L21, diameter $32 \mu \mathrm{m}$.

7 Actinocyclus ehrenbergii var. tenella (Brébisson) Hustedt Sample L9, diameter $25 \mu \mathrm{m}$.

8 Actinocyclus ingens Rattray s. str. (undulated) Sample L23, diameter $145 \mu \mathrm{m}$.

9 Actinocyclus ingens var. nodus Baldauf Sample L21, diameter $42 \mu \mathrm{m}$.

10 Actinocyclus ingens Rattray s. ampl. (flat) Sample L21, diameter $30 \mu \mathrm{m}$. 

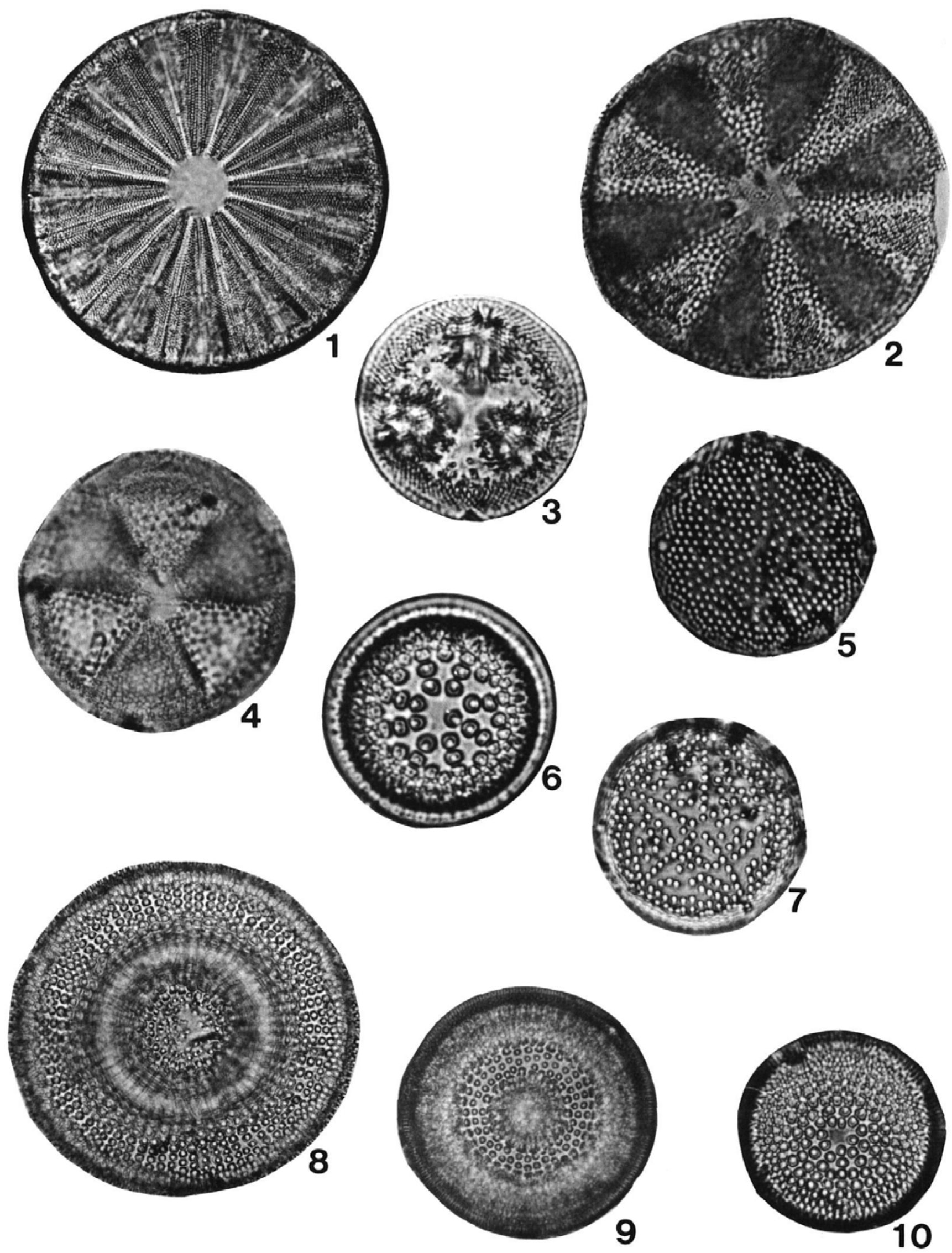
Lithodesmium californicum Grunow in Van Heurck, 1883, pl. 115, fig. 9; Wornardt, 1967, p. 67, fig. 130; Schrader, 1973, p. 706, pl. 12 , figs. 11,20

Macrora stella (Azpeitia) Hanna, 1932, p. 196, pl. 12, fig. 7; Schrader, 1973, p. 706, pl. 12, figs. 21-24. Synonym: Pyxidicula stella Azpeitia, 1911, pp. 150, 153, pl. 1, fig. 1. Remarks: This genus is not a diatom, but is useful as a good guide fossil for Middle Miocene sediments (Schrader, 1973; Hanna, 1932).

Mediaria splendida Sheshukova-Poretzkaya, 1962, p. 210, pl. 2 , fig. 5 ; 1967, p. 306 , pl. 48, figs. 5, 6. [Plate 7, figure 15]

Melosira clavigera Grunow, 1876 in Schmidt et al., 1874-1959, pl. 175, figs. 21-24; Van Heurck, 1882, pl. 91, fig. 2; Barron, 1975, p. 146, pl. 10, fig. 6 .

Melosira sulcata var. biseriata (Grunow) Peragallo and Peragallo, 1908, p. 448, pl. 119, fig. 14; Sheshukova-Poretzkaya, 1967, p. 127. pl. 7, fig. 2; pl. 10, fig. 6. Synonym: Paralia sulcata var. biseriata Grunow, 1884, p. 92, fig. 42.

Melosira sulcata var. siberica Grunow in Van Heurck, 1882, p. 91. fig. 22; Sheshukova-Poretzkaya, 1967, p. 128; Barron, 1975, p. 146, pl. 10, fig. 13.

Melosira varians Agardh, 1827, p. 628; 1832, p. 64; Wolle, 1890 , pl. 57, figs, 11-15; Hustedt, 1927, p. 240, fig. 100.

Navicula hennedyi Wm. Smith, 1856, p. 93; Wornardt, 1967, p. 81, figs. 187, 188; Barron, 1975, p. 147, pl. 10, fig. 16

Navicula lyra Ehrenberg, 1841, p. 419, pl. 1, fig. 9a; Hanna, 1932, p. 199, pl. 13, fig. 2; Wornardt, 1967, p. 82, figs. 189, 190, 192. [Plate 6, figure 4]

Navicula optima Hanna, 1932, p. 202, pl. 13, fig. 6; Wornardt, 1967, p. 84, fig. 193; Barron, 1975, p. 148, pl. 10, fig. 14.

Navicula praetexta Ehrenberg, 1840, p. 214; Hustedt, 1964, p. 411, figs. 1488, 1489; Wornardt, 1967, p. 84, figs. 195-197. Synonym: Pinnularia preissei Ehrenberg, 1854, pl. 19, fig. 28.

Nitzschia challengeri Schrader, 1973, p. 707, pl. 5, figs. 10-14, 34. [Plate 7, figure 16]

Plagiogramma tesellatum Greville, 1859b, p. 208, pl. 10, fig. 7; Wolle, 1890, pl. 45, figs. 18, 19; Hanna and Grant, 1926, p. 162, pl. 19, fig. 10; Hustedt, 1931, p. 107, fig. 633.

Pleurosigma affine Grunow in Cleve and Moller, 1879, no. 172, pp. 208-210; Grunow in Cleve and Grunow, 1880, p. 51; Van Heurck, 1896, p. 252, pl. 6, fig. 263.
Podosira maxima (Kützing) Grunow, 1879, p. 677, pl. 21, fig. 2; Hustedt, 1930, p. 285, fig. 126; Sheshukova-Poretzkaya, 1967, p. 130, pl. 10, fig. 9. Synonym: Cyclotella maxima Kützing, 1844, p. 50, pl. 1, fig. 5; pl. 21, fig. 6 b.

Pseudopyxilla americana (Ehrenberg) Forti, 1909, p. 14, pl. 1, figs. 6, 7; Sheshukova-Poretzkaya, 1967, p. 227, pl. 29, fig. 2; Schrader, 1973, p. 708, pl. 10, fig. 22. Synonym: Rhizosolenia americana Ehrenberg, 1841 (1843), p. 422; 1854, pl. 33, figs. 3, 14, 17.

Raphidodiscus marylandicus Christian, 1887, p. 66-68; Hanna, 1932, p. 208, pl. 14, figs. 3, 4; Schrader, 1973, p. 708, pl. 22, fig. 7. [Plate 3, figure 3]

Rhabdonema japonicum var. sparicostatum Tempère and Brun in Brun and Tempère, 1889, p. 53, pl. 1, fig. 6; Barron, 1975, p. 152 pl. 11, fig. 16.

Rhaphoneis amphiceros Ehrenberg, 1844, p. 87; Hustedt, 1931, p. 174, fig. 680; Hanna, 1932, p. 211, pl. 15, figs. 3-5; Schrader, 1973, p. 708, pl. 25, figs. 2, 3; Lohman, 1974, p. 352, pl. 5, fig. 15. [Plate 7, figure 19]

Rhaphoneis miocenica Schrader, 1973, p. 709, pl. 25, figs. 1, 11. [Plate 5, figure 5]

Rhaphoneis paralis Hanna, 1932, p. 214, pl. 16, figs. 2-4; Proschkina-Lavrenko, 1949, p. 219, pl. 99, fig. 3.

Rhizosolenia styliformis Brightwell, 1858, p. 95, pl. 5, fig. 5a; Hustedt, 1930, pp. 584-588, figs. 333-335; Barron, 1975, p. 153, pl. 12, fig. 6 .

Rouxia diploneides Schrader, 1973, p. 710, pl. 3, figs. 27-32. [Plate 7, figures 9-10]

Rouxia naviculoides Schrader, 1973, p. 710, pl. 3, figs. 27-32.

Stephanogonia polyacantha Forti, 1913, p. 1560, pl. 12, fig. 11; Hanna, 1932, p. 218, pl. 16, fig. 8; Barron, 1975, p. 154, pl. 12, fig. 13.

Stephanopyxis schenckii Kanaya, 1959, p. 67, pl. 2, figs. 2-4; Koizumi, 1973, p. 833, pl. 6, figs. 11, 12; Barron, 1975, p. 155, pl. 12, fig. 19.

Stephanopyxis turris (Greville and Arnott) Ralfs in Pritchard, 1861, p. 826, pl. 5, fig. 74; Karsten, 1905, p. 73, pl. 2, fig. 1; Hustedt, 1928, p. 304, fig. 140. Synonym: Cresswellia turris Greville and Arnott, 1857, p. 538, fig. 64.

Stictodiscus californicus Greville, 1861, p. 79, pl. 10, fig. 1; Hanna and Grant, 1926, p. 167, pl. 20, fig. 12; Wornardt, 1967, p. 38, figs. $54,55$.

\section{PLATE 2}

\section{Scanning electron micrographs}

1-4 Coscinodiscus volutus Baldauf, $\mathrm{n} . \mathrm{sp}$.

1, lateral view, subcircular areolae pattern, sample L10, diameter of individual $93 \mu \mathrm{m}$, isotype, USNM $311179 ; 2$, closeup of hyaline intervals along margin, sample L10, diameter of individual $93 \mu \mathrm{m}$, isotype, USNM $311179 ; 3$, view of submarginal labiate processes on underside of valve, sample L10, diameter of individual $80 \mu \mathrm{m}$, isotype, USNM 311180; 4, closeup of valve center, showing slightly depressed center, and distinct central nodule, sample L10, diameter of individual $93 \mu \mathrm{m}$, isotype, USNM 311180. 

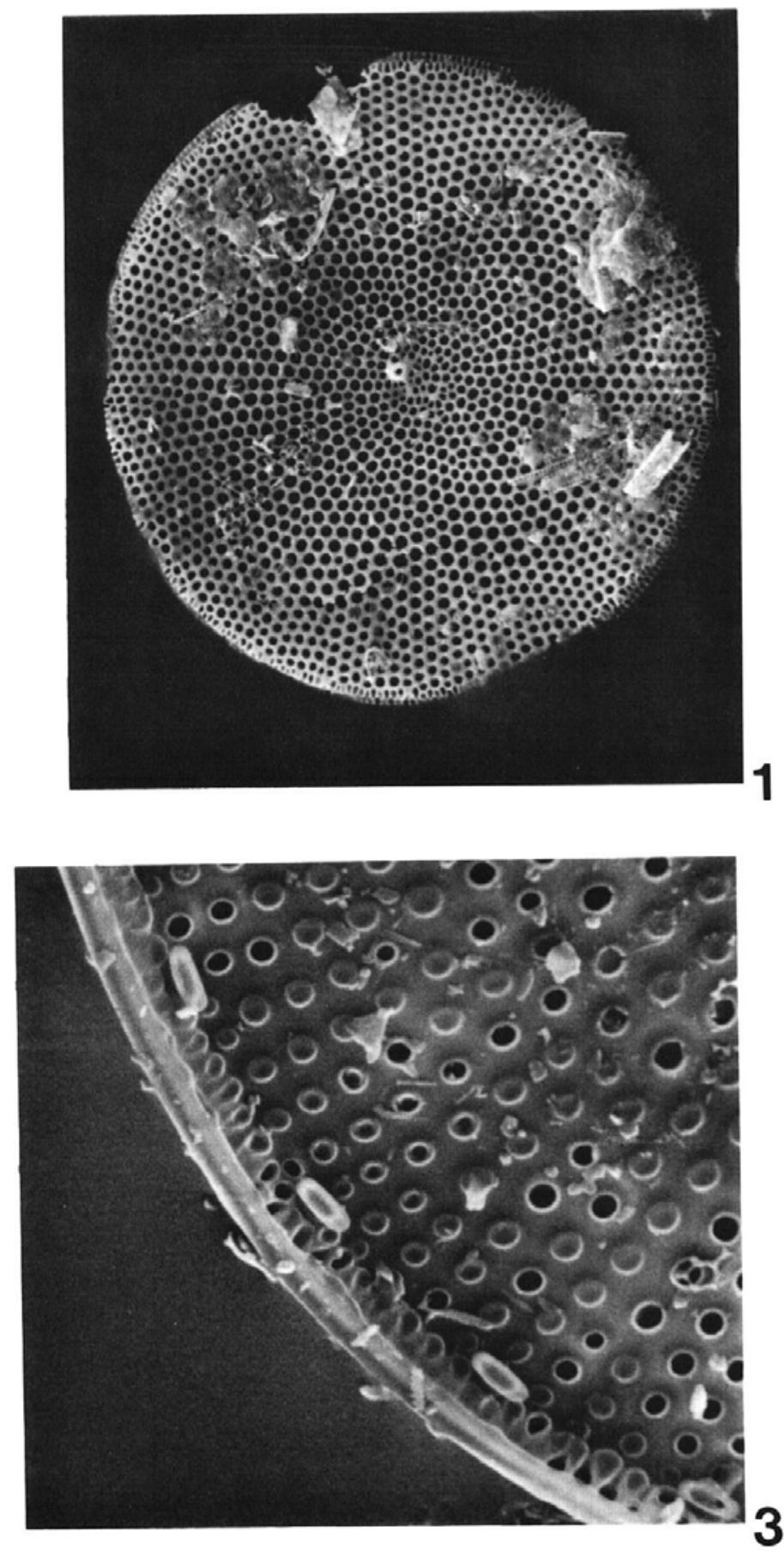
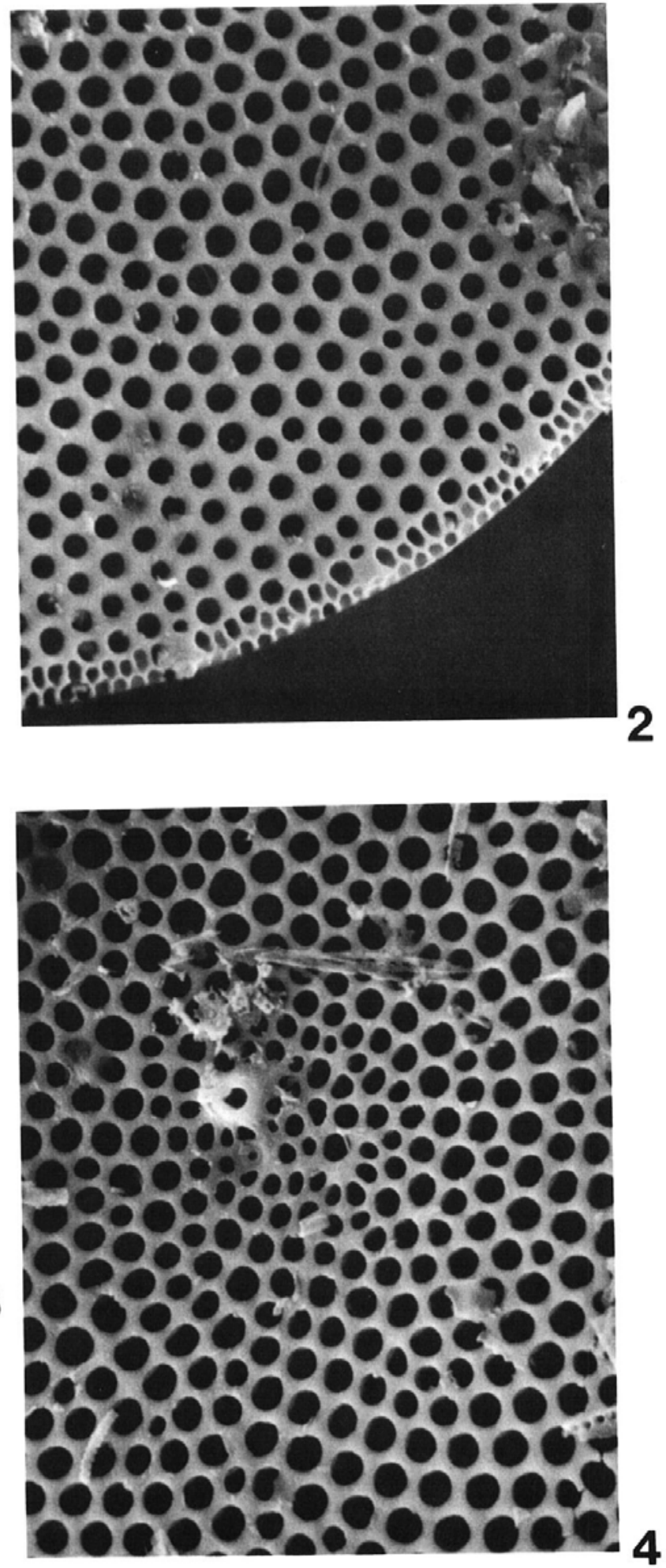
Syndendrium diadema Ehrenberg, 1845, p. 155; Lohman, 1974, p. 350 , pl. 5 , fig. 13.

Synedra jouseana Sheshukova-Poretzkaya, 1962, p. 208, fig. 4; Schrader, 1973, p. 710, pl. 23, figs. 21-23, 25, 38; Barron, 1975, p. 156, pl. 13, fig. 4. [Plate 7, figure 13]

Thalassionema nitzschioides Grunow in Van Heurck, 1896, p. 319, fig. 75; Hustedt, 1932, p. 244, fig. 725; Schrader, 1973, p. 712, pl. 23 , figs. $2,6,8-10,26$.

Thalassiosira leptopus (Grunow) Hasle and Fryxell, 1977, pp. 2022, figs. 1-14. Synonym: Coscinodiscus lineatus Ehrenberg, 1838, p. 129 ; 1841 , p. 146 , pl. 3 , fig. 4 ; Rattray, 1890 a, p. 472 , fig. 24 ; Hanna, 1932, p. 180, pl. 8, figs. 1-3; Lohman, 1974, p. 335, pl. 2, fig. 3. [Plate 4 , figure 2]

Thalassiosira sp. 1. Synonym: Thalassiosira sp. 2 Schrader, 1973, p. 712 , pl. 14 , figs. $17-18$.

Thalassiothrix longissima Cleve and Grunow, 1880, p. 108; Hustedt, 1932, p. 247, fig. 726; Lohman, 1974, p. 353, pl. 6, fig. 2. [Plate 7, figures 11-12]

Triceratium condecorum Ehrenberg, 1844b, p. 272; Brightwell, 1853 , p. 250, pl. 4, fig. 12; Wolle, 1890, pl. 102, fig. 6; Hanna, 1932, p. 221 , pl. 17, figs. 1,3 .

Xanthiopyxis globosa Ehrenberg, 1844b, p. 273; De Toni, 1894, p. 1155; Hanna, 1932, p. 224, pl. 18, fig. 3; Barron, 1975, p. 161 , pl. 15, figs. $8,9$.

Xanthiopyxis maculata Hanna, 1932, p. 255, pl. 18, fig. 4.

Xanthiopyxis ovalis Lohman, 1938, p. 91, pl. 20, fig. 6; pl. 22, fig. 12; Barron, 1975, p. 161, pl. 15, fig. 13.

\section{ACKNOWLEDGMENTS}

We thank Earl Brabb, R. Z. Poore, K. McDougall, and S. A. Kling for assistance in collecting the samples. Kristin McDougall and R. Z. Poore also provided helpful comments throughout the study. The manuscript was reviewed by G. Andrews, K. McDougall and R. Z. Poore. Appreciation is also due Rose Trombley for typing the manuscript and Robert Oscarson for SEM (scanning electron microscope) work.

\section{REFERENCES}

ABBOTT, W. H., and ANDREWS, G. W., 1979. Middle Miocene marine diatoms from the Hawthorn Formation within the Ridge- land Trough, South Carolina and Georgia. Micropaleontology, 25(3): 225-271, pls. 1-8.

ADDICOTT, W. O., 1970. Tertiary paleoclimatic trends in the San Joaquin Basin, California. U.S. Geol. Surv., Prof. Paper 644-D:19 pp.

ADDICOTT, W. O., POORE, R. Z., BARRON, J. A., GOWER, H. D., and MCDOUGALL, K., 1978. Neogene biostratigraphy of the Indian Creek-Shell Creek area, northern La Panza Range, California. U.S. Geol. Surv., Open-File Rept. 78-446:49-81.

AGARDH, C. A., 1827. Aufzählung einiger in den östreichischen Ländern gefundenen neue Gattungen und Arten von Algen nebst ihrer Diagnostik und beigefügten Bemerkungen. "Flora oder botanische Zeitung," 10:625-646. Regensburg.

1828-1836. Icones Algarum Europaerum. Representation d'algues européenes suivie de celle des espèces exotiques les plus remarquables récemment découvertes, vols. 1-4. Leipzig.

ANDREWS, G. W., 1975. Taxonomy and stratigraphic occurrence of the marine diatom genus Rhaphoneis. Nova Hedwigia, Beih. 53:193-222

1976. Miocene marine diatoms from the Choptank Formation, Calvert County, Maryland. U.S. Geol. Surv., Prof. Paper 910:1-24.

1977. Morphology and stratigraphic significance of Delphineis, a new marine diatom genus. Nova Hedwigia, Beih., 54:243260 .

AZPEITIA MOROS, F., 1911. La Diatomologia Española en los comienzos del siglo XX. Asoc. Española Prog. Cienc. Congr. Zaragoza, 4:1-320.

BAILEY, J. W., 1842. A sketch of the Infusoria of the family Bacillaria, etc. Amer. Jour. Sci., 42:88-105.

1844. Account of some new infusorial forms discovered in the fossil Infusoria from Petersburg, Va., and Piscataway, Md. Amer. Jour. Sci., 46:137-141.

1853 (1854). Notes on new species and localities of microscopical organisms. Smithsonian Contr. Knowl., 7(3):1-16.

BALDAUF, J. G., and BARRON, J. A., 1980. Actinocyclus ingens var. nodus: a new stratigraphically useful diatom of the circumNorth Pacific. Micropaleontology, 26(1):103-110, pl. 1.

BARRON, J. A., 1975. Late Miocene-Early Pliocene marine diatoms from southern California. Palaeontographica, 151(B):97-170.

1976. Revised Miocene and Pliocene diatom biostratigraphy

\section{PLATE 3}

1 Coscinodiscus obscurus Schmidt

Sample L10, diameter $90 \mu \mathrm{m}$.

2 Coscinodiscus volutus Baldauf, $\mathrm{n}$. sp. Sample L10, diameter $87 \mu \mathrm{m}$. Holotype, USNM 311178.

3 Raphidodiscus marylandicus Christian Sample L10, diameter $32 \mu \mathrm{m}$.
4 Coscinodiscus praeyabei Schrader

Sample L24, diameter $18 \mu \mathrm{m}$.

5-7 Coscinodiscus vetustissimus Pantocsek 5 , Sample L10, diameter $68 \mu \mathrm{m} ; 6$, closeup of central region. Notice hyaline ring around central areolae, sample L10, width of photograph $18 \mu \mathrm{m} ; 7$, sample L10, diameter $70 \mu \mathrm{m}$. 

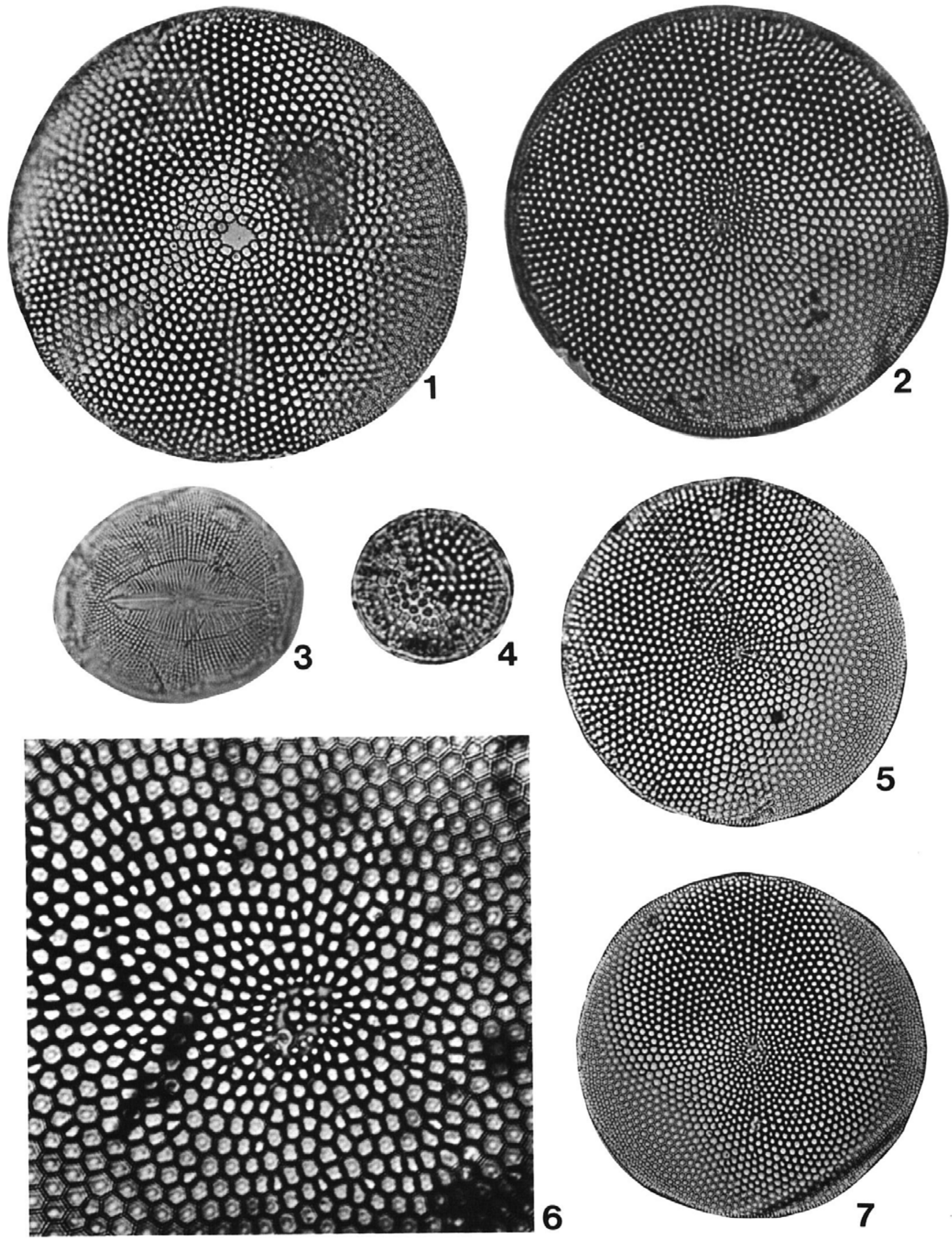
of Upper Newport Bay, Newport Beach, California. Marine Micropal., 1:27-63.

-1980. Miocene to Quaternary diatom biostratigraphy of DSDP Leg 57, off northeast Japan. In: Scientific Party, Initial Reports of the Deep Sea Drilling Project, volumes 56, 57(2):641685. Washington, D.C.: U.S. Government Printing Office.

1981. Late Cenozoic diatom biostratigraphy and paleoceanography of the middle-latitude eastern North Pacific. In: Yeats, R., Haq, B. U., et al., Initial Reports of the Deep Sea Drilling Project, volume 63:507-538. Washington, D.C.: U.S. Government Printing Office.

BLOW, W. H., 1969. Late Middle Eocene to Recent planktonic foraminiferal biostratigraphy. First International Conference on Planktonic Microfossils, Geneva, Switzerland, Proc., 1967:199_ 421.

BOYER, C. S., 1926-1927. Synopsis of North American Diatomaceae. Acad. Nat. Sci. Philadelphia, Proc., 78, supplement (1):1288 (1926): 79, supplement (2):229-583 (1927).

BRÉBISSON, A., 1857. Refermant la description de quelques nouvelles Diatomées observées dans le Guano de Pérou, et formant le genre Spatangidium. Soc. Linnéenne Normandie, Bull., 2(1st ser.):292-298, pl. 3

BRÉBISSON, A. de and GODEY, 1838, Considérations sur les Diatomées et essai d'une classification des genres et des espèces appartenant à cette famille. Falaise 1838:1-20.

BRIGHTWELL, T., 1853. On the genus Triceratium with descriptions and figures of the species. Quart. Jour. Micros. Sci., 1:245-252, pl. 4.

- 1858. Remarks on the genus "Rhizosolenia" of Ehrenberg. Quart. Jour. Micros. Sci., 6:93-95, pl. 5.

BRUN, J., 1891. Diatomées espèces nouvelles marines, fossiles ou pélagiques. Soc. Phys. d'Hist. Nat. Genève, Mem., 31(1):1-47.

BRUN, J., and TEMPĖRE, J., 1889. Diatomées fossiles du Japon. Espèces marines et nouvelles des calcaires argilleux de Sendai et de Yedo. Soc. Phys. d'Hist. Nat. Genève, Mem., 30(9):1-75.

BUKRY, D., 1973. Low-latitude coccolith biostratigraphic zonation. In: Edgar, N. T., Saunders, J. B., et al., Initial Reports of the Deep Sea Drilling Project, volume 15:685-703. Washington, D.C.: U.S. Government Printing Office.

1975. Coccolith and silicoflagellate stratigraphy, northwestern Pacific Ocean, Deep Sea Drilling Project Leg 32. In: Larson,
R. L., Moberly, R., et al., Initial Reports of the Deep Sea Drilling Project, volume 32:677-701. Washington, D.C.: U.S. Government Printing Office.

BURCKLE, L. H., 1978. Early Miocene to Pliocene diatom datum levels for the equatorial Pacific. Republic of Indonesia, Geol. Res. Devel. Centre, Spec. Publ. no. 1:25-44.

CASTRACANE, CONTE A., 1875. Contribuzione alla florula della Diatomee del Mediterraneo ossia esame del contenuto dello stomaco di una Salpa pinnata, pescata a Messina. Atti Accad. Pont. Nuovi Lincei, 28:377-396.

1886. Report on the scientific results of the voyage of H.M.S. Challenger during the years 1873-76. Repts. Voy. Challenger, Botany, 2:1-178, pls. 1-23.

CHRISTIAN, T., 1887. New diatomaceous deposits. Amer. Monthly Micros. Jour. (The Microscope), 7(3):65-68.

CLEVE, P. T., 1894-1895. Synopsis of the naviculoid diatoms. K. Svenska Vetensk.-Akad., Handl., 26(1):1-194, pls. 1-5 (1894); 27(2):1-219, pls. 1-4 (1895).

CLEVE, P. T., and GRUNOW, A., 1880. Beiträge zur Kenntniss der artischen Diatomeen. K. Svenska Vetensk.-Akad., Handl., 17(2): 1-121, pls. $1-7$.

CLEVE, P. T., and MOLLER, J. D., Eds., 1877-1882. Diatoms (Exsiccata). Parts 1-6. Uppsala.

CLEVE-EULER, A., 1951-1955. Die Diatomeen von Schweden und Finnland. K. Svenska Vetensk.-Akad., Handl., 2(1):1-163, figs. 1294, 6 pls. (Pt. I, Centricae, 1951).

CROUCH, J. K., and BUKRY, D., 1979. Comparison of Miocene provincial stages to coccolith zones in the California Continental Borderland. Geology, 7:211-215.

CUSHMAN, J. A., 1926. Foraminifera of the typical Monterey of California. Cushman Lab. Foram. Res., Contr., 2(3):53-66.

DE TONI, G. B., 1894. Bacillarieae. Section I, Raphideae, 1-490 (1891). Section II, Pseudoraphideae, 491-817 (1892). Section III, Cryptoraphideae, 818-1556 (1894).

EHRENBERG, C. G., 1838. Die Infusionsthierchen als vollkommende Organismen. Ein Blick in das tiefere organische Leben der Natur. Leipzig: Leopold Voss, 1-548, pls. 1-64.

, 1839. Über nach jetzt zahlreich lebende Thierarten der Kreidebildung und den Organismus der Polythalamien. K. Akad. Wiss. Berlin, Abhandl., 81-174.

\section{PLATE 4}

1 Coscinodiscus symbolophorus Grunow Sample L21, diameter $22 \mu \mathrm{m}$. High and low focus.

2 Thalassiosira leptopus (Grunow) Hasle and Fryxell Sample L22, diameter $75 \mu \mathrm{m}$.

3, 5, 8 Coscinodiscus tuberculatus Greville 3, sample L10, diameter $32 \mu \mathrm{m}$; 5, sample
L10, diameter $32 \mu \mathrm{m}$; 8, sample L10, diameter $37 \mu \mathrm{m}$.

4 Coscinodiscus salisburyanus Lohman Sample L10, diameter $29 \mu \mathrm{m}$.

\section{6-7 Coscinodiscus tabularis Grunow}

6, sample L10, diameter $34 \mu \mathrm{m} ; 7$, sample L8, diameter $25 \mu \mathrm{m}$. 

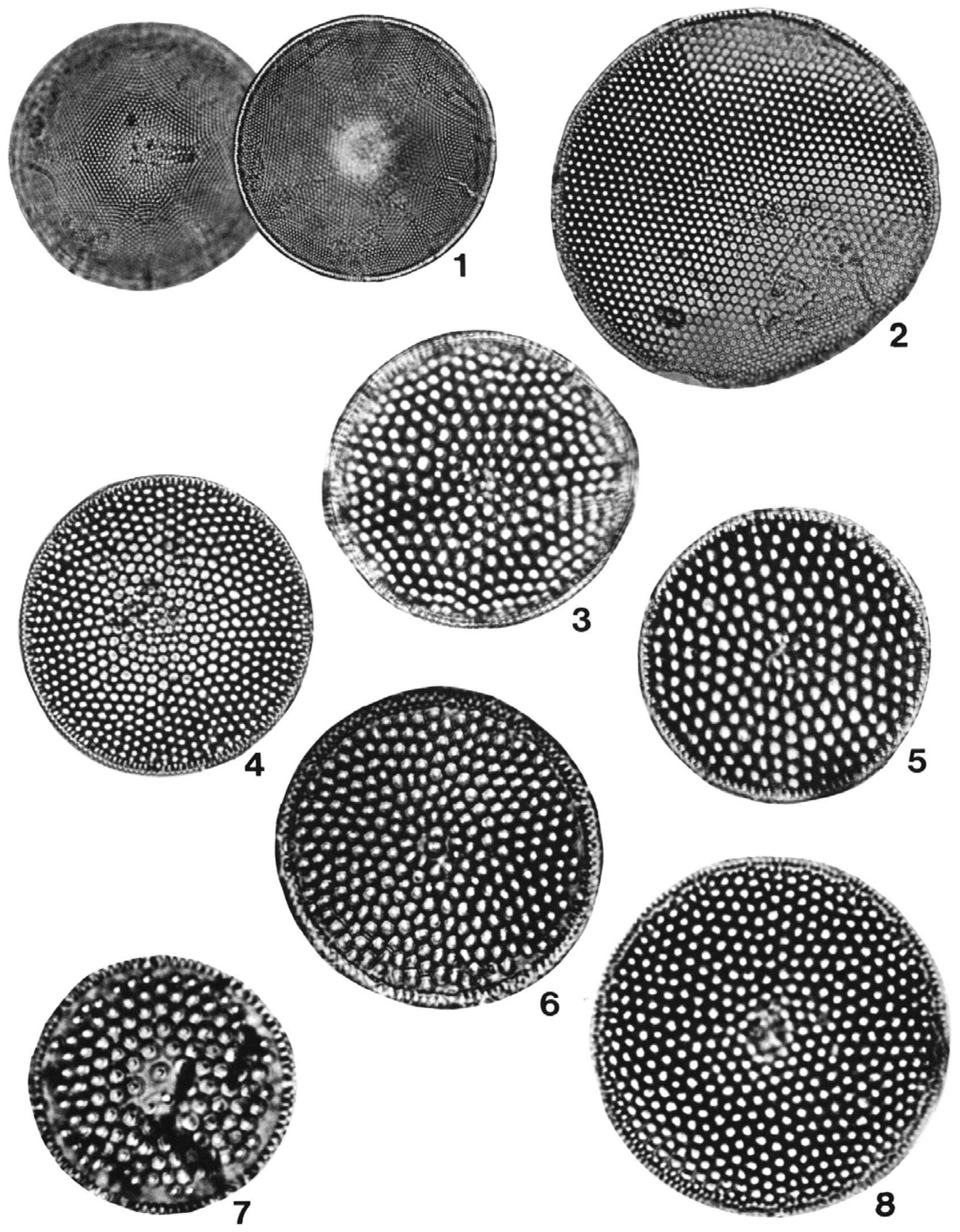
- 1840. "Characteristik von 274 neyen Arten von Infusorien." (This is an article title as given in the index volume to this journal; apparently, the article itself does not have a title.) K. Preussischen Akad. Wiss. Berlin, Verhandl., 197-219.

, 1841a. Über Verbreitung und Einfluss des mikroskopischen Lebens in Süd- und Nord-Amerika. K. Preussischen Akad. Wiss. Berlin, Verhandl., 139-144.

- 1841b, Über Verbreitung und Einfluss des mikroskopischen Lebens in Süd- und Nord-Amerika. K. Preussischen Akad. Wiss. Berlin, Verhandl., 1:291-445, 4 pls.

—_ 1844a. Über zwei neue Lager von Gebirgsmassen aus Infusorien als Meeres-Absatz in Nord-Amerika und eine Vergleichung derselben mit den organischen Kreide-Gebilden in Europa und Afrika. K. Preussischen Akad. Wiss. Berlin, Verhandl., 1844: 57-97.

1844b. Untersuchungen über die kleinsten Lebensformen im Quellenlande des Euphrats und Araxes, so wie über eine an neuen Tormen sehr reiche, marine Tripelbildung von den Bermuda-Inseln. K. Preussischen Akad. Wiss. Berlin, Verhandl., 253275.

— 1845. Vorläufige zweite Mittheilung über die Beziehungen des kleinsten organischen Lebens zu den vulkanischen Massen der Erde. K. Preussischen Akad. Wiss. Berlin, Verhandl., 133-157.

, 1854-1856. Mikrogeologie. Das Erden und felsen schaffende Wirken des unsichtbar kleinen selbstständigen Lebens auf der Erde. Leipzig: Leopold Voss, 374 pp. (1854), 40 pls.

FENNER, J., 1978. Cenozoic diatom biostratigraphy of the equatorial and southern Atlantic Ocean. In: Supko, P. R., Perch-Nielsen, K., et al., Initial Reports of the Deep Sea Drilling Project, v. supplement 38-41:491-623. Washington, D.C.: U.S. Government Printing Office.

FORTI, A., 1908-1909. Studi per una Monografia del genere Pyxilla (Diatomee) e dei generi affini. Nuova Notarisia, ser. 20, pls. 1-2.

—, 1913. Contribuzioni diatomologiche. XIII. Diagnoses Diatomacearum quarundam fossilium italicarum. Reale Inst. Veneto Sci., Atti, 71(2):1535-1700.

FRENGUELLI, J., 1949. Diatomeas fossiles de las yacimientos chilenos de Tiltil y Mejillones. Darwiniana, 9(1):97-157.

FRICKE, F., 1902. Verzeichnis der in A. Schmidt's Atlas der Diatomaceenkunde, Tabel 1-240 (Serie I-V) adgebildeten und benannten Formen. Leipzig: Dr. Friedr. Fricke, 69 S.O.R. Reisland.
GOMBOS, A. M., JR., 1975. Fossil diatoms from Leg 7, Deep Sea Drilling Project. Micropaleontology, 21(3):306-333, pls. 1-8.

GRAN, H. H., 1897. Bacillariaceen vom Kleinen Karajakfjord. Bibl. Bot., 42:13-24.

GREGORY, W., 1855. On some new species of British fresh water Diatomaceae, with remarks on the value of certain specific characters. Bot. Soc. Edinburgh, Proc., 1855, pp. 38-39.

1857. On some new forms of marine Diatomaceae found in the Firth of Clyde and in Loch Fyne, illustrated by numerous figures drawn by R. K. Greville, LL.D., F.R.S.E. Roy. Soc. Edinburgh, Trans., 21:473-542, 6 pls.

GREVILLE, R. K., 1859a. Descriptions of Diatomaceae observed in Californian guano. Bot. Soc. Edinburgh, Trans., 6:245-249, pl. 5. Also see Quart. Jour. Micros. Sci., 7:155-166, pls. 7, 8.

- 1859b. On Plagiogramma, a new genus of Diatomaceae. Quart. Jour. Micros. Sci., 7:207-224, pl. 10.

1861. Description of new and rare diatoms. Micros. Soc. London, Trans., 9, n. ser. (ser. 1):39-45; (ser. II):67-73; (ser. III):73-79; (ser. IV):79-87.

1862. Description of new and rare diatoms. Micros. Soc. London, Trans., 10 (ser. V):18-29; (ser. VI):89-97.

1865. Description of new and rare diatoms. Micros. Soc. London, Trans., 13 (ser. XIV):1-10; (ser. XV):24-34; (ser. XVI): 43-75; (ser. XVII):97-105.

- 1866. Description of new and rare diatoms. Micros. Soc. London, Trans., 14 (ser. XVIII):1-9; (ser. XIX):77-86; (ser. $X X): 121-130$.

GREVILLE, R., and ARNOTT, G. W., 1857. In: Gregory, W., On new forms of marine Diatomaceae found in the Firth of Clyde and in Loch Fyne. Roy. Soc. Edinburgh, Trans., 21:473-542.

GRUNOW, A., 1868. Beiträge zur Kenntniss der Schizonema- und Berkeleya-Arten. Hedwigia, 7(1):1-7.

1870. Algae. In: Reise der österreichischen Fregatte Novara um die Erde in den Jahren 1857, 1858, 1859. (Bot.), 1:1-104.

, 1879. Algen und Diatomaceen aus dem Kaspischen Meere. [New species and varieties of Diatomacea from the Caspian Sea.] Jour. Roy. Micros. Soc., 2 (1879):677-691.

1884. Die Diatomeen von Franz Josefs-Land. K. Akad. Wiss. Wien Math.-Nat. KI. Denkschr., 48:53-112, pls. 1A-5E.

PLATE 5

1 Coscinodiscus oculus-iridis Ehrenberg Sample L18, diameter $107 \mu \mathrm{m}$.

\section{2-3 Coscinodiscus marginatus Ehrenberg}

2, sample L4, diameter $98 \mu \mathrm{m} ; 3$, sample L4, diameter $81 \mu \mathrm{m}$.
4, 6 Annellus californicus var. hannai Barron 4, sample L9, diameter $85 \mu \mathrm{m}$; 6, sample L9, diameter $50 \mu \mathrm{m}$.

5 Rhaphoneis miocenica Schrader Sample L5, diameter $48 \mu \mathrm{m}$.

7 Coscinodiscus sp. cf. C. marginatus Ehrenberg Sample L17, diameter $67 \mu \mathrm{m}$. 

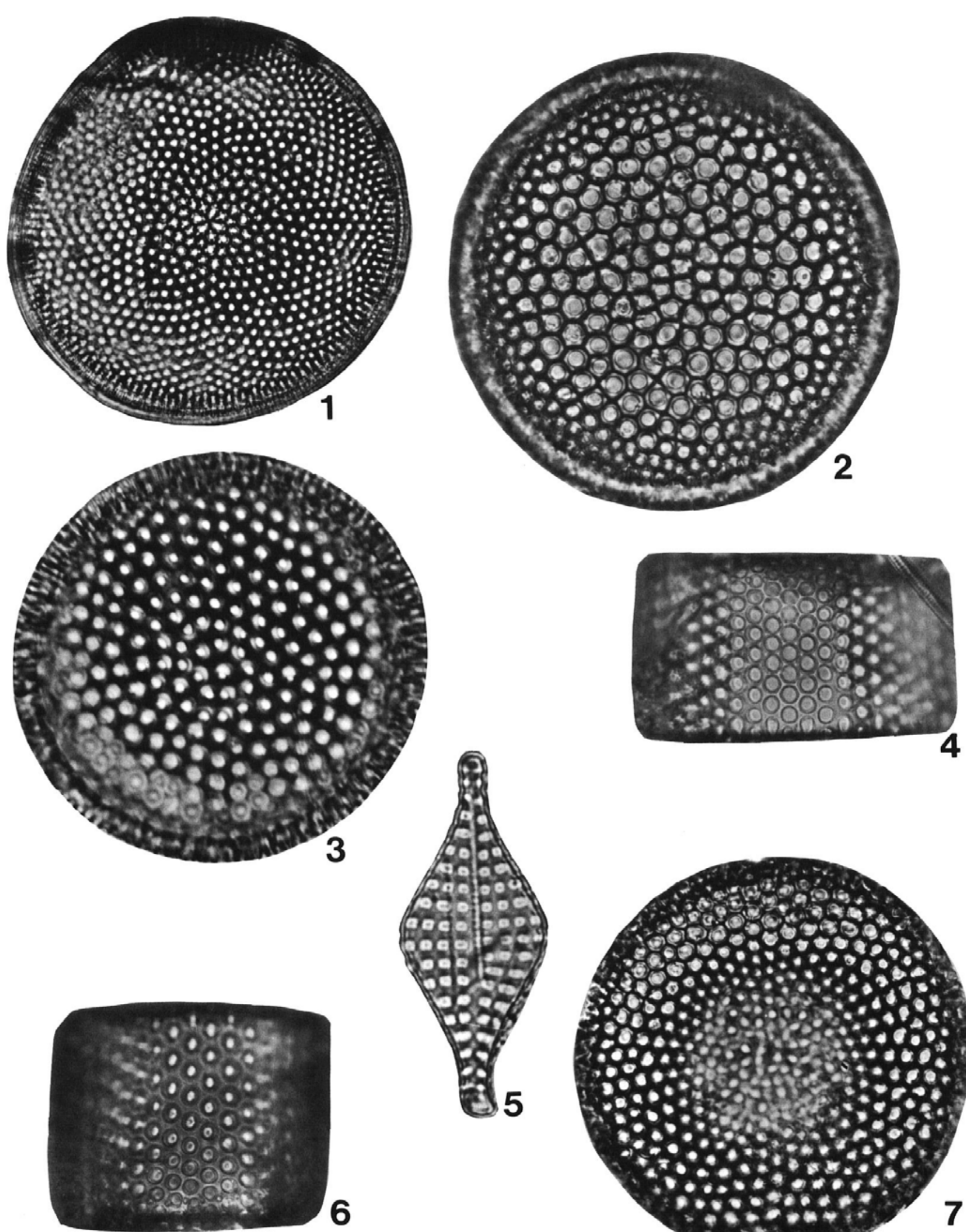
1888. In: Referat-Grove and Sturt, On a fossil marine diatomaceous deposit from Oamaru, Otago, New Zealand. Bot. Centralbl., 34:34-41.

HANNA, G. D., 1932. The diatoms of Sharktooth Hill, Kern County, California. California Acad. Sci., Proc., ser. 4, 20(6):161-263, pls. 2-18.

HANNA, G. D., and GRANT, W. M., 1926. Expedition to the Revillagigedo Islands, Mexico, in 1925. II. Miocene marine diatoms from Maria Madre Island, Mexico. California Acad. Sci., Proc., ser. 4, 15(2):115-193, pls. 11-21.

HASLE, G. R., and FRYXELL, G. A., 1977. The genus Thalassiosira: Some species with a linear areola array. Nova Hedwigia, Beih., $54: 15-66$.

HENDEY, N. I., 1964. An introductory account of the smaller algae of British coastal waters. Part V. Bacillariophyceae (diatoms). London: Min. Agr. Fish. Food, Fish. Inv., ser. 4:1-317.

HUSTEDT, F., 1927-1966. Die Kieselalgen Deutschlands, Österreichs und der Schweiz. Band 7 of Rabenhorst, F. L., Kryptogamenflora. Leipzig: Akad. Verlagsges., pt. 1:1-920, figs. 1-542, 1927-1930; pt. 2:1-845, figs. 543-1179, 1931-1959; pt. 3:1816 , figs. $1180-1788,1962-1966$.

INGLE, J. C., JR., 1973. Summary comments on Neogene biostratigraphy, physical stratigraphy, and paleo-oceanography in the marginal northeastern Pacific Ocean. In: Kulm, L. D., and von Huene, R., et al., Initial Reports of the Deep Sea Drilling Project, volume 18:949-960. Washington, D.C.: U.S. Government Printing Office.

JOUSÉ, A. P., 1974. Diatoms in the Oligocene-Miocene biostratigraphic zones of the tropical areas of the Pacific Ocean. Nova Hedwigia, Beih., 45:333-364

- Ed., 1977. Atlas of microorganisms in bottom sediments of the oceans: Diatoms, Radiolaria, silicoflagellates, and coccoliths. Nauka, Moscow.

JOUSÉ, A. P., KOZLOVA, O. G., and MUHINA, V. V., 1971. Distribution of diatoms in the surface layer of sediment from the Pacific Ocean. In: Funnell, B. M., and Riedel, W. R., Eds., The micropaleontology of the oceans. London: Cambridge Univ. Press, 263269.

KANAYA, T., 1959. Miocene diatom assemblages from the Onnagawa Formation and their distribution in the correlative formations in northeast Japan. Tohoku Univ. Sci. Repts., ser. 2 (Geol.), 30:1130.
1971. Some aspects of pre-Quaternary diatoms in the oceans. In: Funnell, B. M., and Riedel, W. R., Eds., The micropaleontology of the oceans. London: Cambridge Univ. Press, 545-565, pls. 40.1-40.6.

KANAYA, T., and KOIZUMI, I., 1966. Interpretations of diatom thanatocoenoses from the North Pacific applied to a study of core V20-130 (Studies of deep-sea core V20-130, part 4). Tohoku Univ. Sci. Rept., ser. 2 (Geol.), 37(2):89-130.

KARSTEN, G., 1905-1907. Wissenschaftliche Ergebnisse der Deutschen Tiefsee-Expedition auf dem Dampfer "Valdivia" 18981899, herausgegeben von Carl Chun. Band II, Teil II. G. Karsten. Das Phytoplankton des antarktischen Meeres nach dem Material der deutschen Tiefsee-Expedition 1898-1899, pp. 1-136 (1905). Das Phytoplankton des Atlantischen Oceans nach dem Material der Deutschen Tiefsee-Expedition 1898-1899, pp. 137-219 (1905). Das indische Phytoplankton nach dem Material der deutschen Tiefsee-Expedition 1898-1899, pp. 221-548 (1907). Jena.

1928. Abteilung Bacillariophyta (Diatomeae). In: Engler, A., and Prantl, K., Die natürlichen Pflanzenfamilien, edition 2, vol. 2, Peridineae (Dinoflagellatae), Diatomeae (Bacillariophyta), Myxomycetes: 105-345, text-figs. 93-447. Leipzig: Wilhelm Engelmann.

KENNETT, J. P., 1977. Cenozoic evolution of Antarctic glaciation, the circum-Antarctic Ocean, and their impact on global paleoceanography. Jour. Geophys. Res., 82(27):3843-3860.

KISSELEV, I. A., 1931. Das Phytoplankton und seine Verteilung im Liman von Amur. Issledovanie (Dal'nevostochnykh) morei S.S.S.R. (Moskva-Leningrad), 14:31-116.

KLEINPELL, R. M., 1938. Miocene stratigraphy of California. Tulsa, Okla.: Amer. Assoc. Petr. Geol., 450 pp.

KOLBE, R. W., 1954. Diatoms from the equatorial Pacific cores. Swedish Deep-Sea Exped., Rept., 6(1):1-49, pls. 1-4.

KOIZUMI, I., 1968. Tertiary diatom flora of Oga Peninsula, Akita Prefecture, northeast Japan. Tohoku Univ. Sci. Repts., ser. 2 (Geol.), 40:171-240

1973. The Late Cenozoic diatoms of Sites 183-193, Leg 19, Deep Sea Drilling Project. In: Creager, J. S., Scholl, D. W., et al., Initial Reports of the Deep Sea Drilling Project, volume 19:805855. Washington, D.C.: U.S. Government Printing Office.
1 Cocconeis scutellum Ehrenberg Sample L28, length $142 \mu \mathrm{m}$.

2 Biddulphia tuomeyi (Bailey) Roper Sample L8, length $125 \mu \mathrm{m}$.

3 Hyalodiscus radiatus (O'Meara) Grunow Sample L6, diameter $80 \mu \mathrm{m}$.
4 Navicula lyra Ehrenberg Sample L5, length $134 \mu \mathrm{m}$.

5 Arachnoidiscus ornatus var. montereyanus Schmidt Sample L7, diameter $156 \mu \mathrm{m}$.

6 Aulacodiscus kittoni Arnott ex Ralfs Sample L6, diameter $71 \mu \mathrm{m}$. 


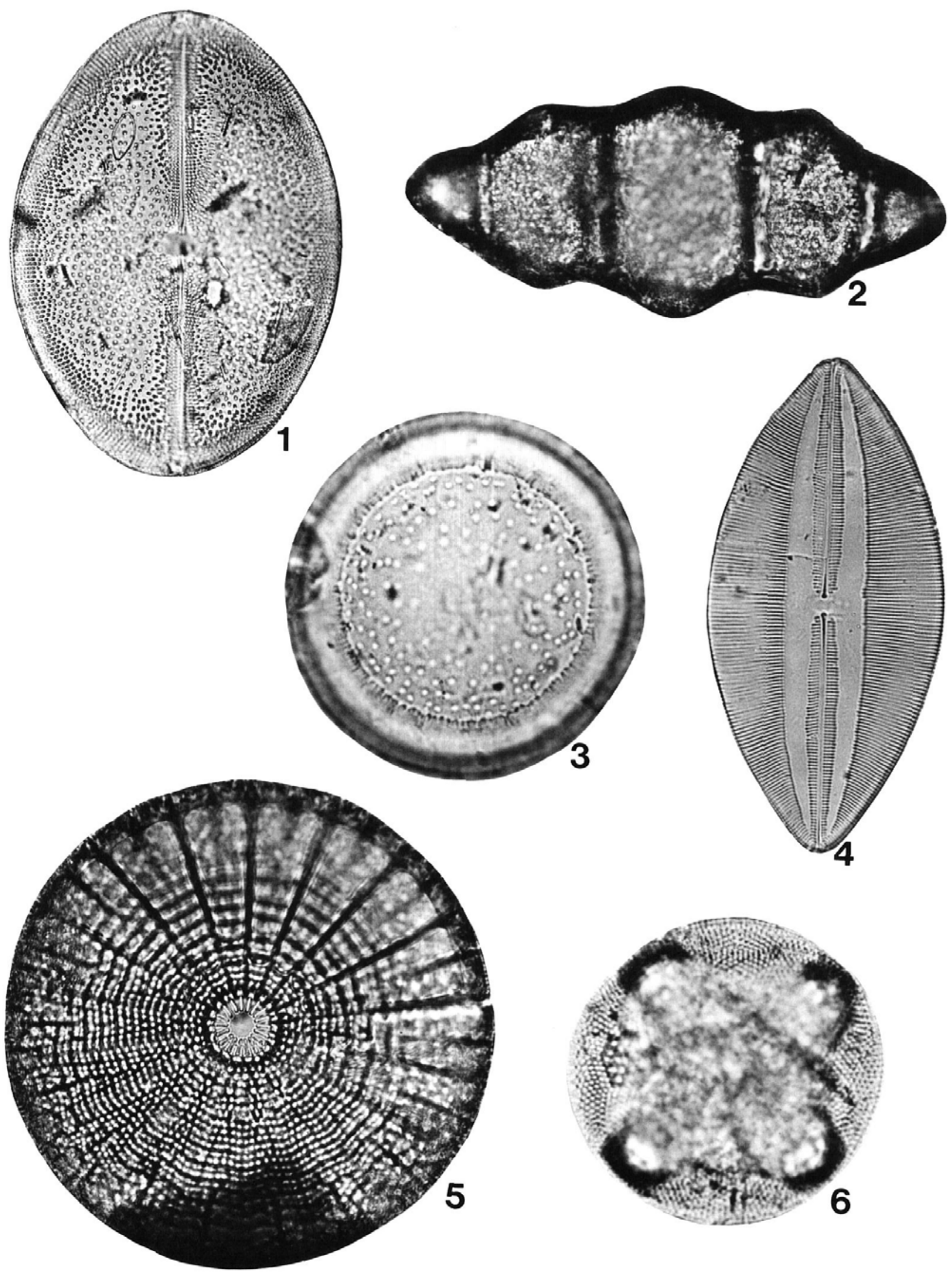


KÜTZING, F. T., 1844-1865. Die kieselschäligen Bacillarien oder Diatomeen. Nordhausen, 1-152.

LIPPS, J. H., 1967. Planktonic foraminifera, intercontinental correlation and age of California mid-Cenozoic microfaunal stages. Jour. Pal., 41:994-999.

LIPPS, J. H., and KALISKY, M., 1972. Calcareous nannoplankton biostratigraphy and paleoecology. In: Stinemeyer, E. H., Ed., Pacific coast Miocene biostratigraphic symposium. Soc. Econ. Pal. Mineral. Proc., Pacific Sec., Bakersfield, California, 239-254.

LOHMAN, K. E., 1938. Pliocene diatoms from the Kettleman Hills, California. U.S. Geol. Surv., Prof. Paper 189-C:81-102.

_ 1948. Middle Miocene diatoms from the Hammond Well. In: Cretaceous and Tertiary subsurface geology. Maryland Dept. Mines, Geol., Bull., 2:151-187, 332-333.

_ 1974. Lower middle Miocene marine diatoms from Trinidad. Naturf. Ges. Basel, Verhandl., 84(1):326-360.

LYNGBYE, H. C., 1819. Tentamen Hydrophytologiae Danicae Continens omnia Hydrophyta Cryptogama Daniae, Holsatiae, Faeroae, Islandiae, Groenlandiae hucusque cognita, Systematicae Disposita, Descripta et Iconibus Illustrata, Adjectis Simul Speciebus Norvegicis. Hafniae, 1-248.

MALLORY, V. A., 1959. Lower Tertiary biostratigraphy of the California Coast Ranges. Tulsa, Okla.: Amer. Assoc. Petr. Geol., 416 pp.

MANKINEN, E. A., and DALRYMPLE, G. B., 1979. Revised geomagnetic polarity time scale for the interval 0-5 m.y.B.P. Jour. Geophys. Res., 84(B2):615-626.

MANN, A., 1907. Report on the diatoms of the Albatross voyages in the Pacific Ocean, 1888-1904. U.S. Natl. Herbarium Contr., 10(5): $221-419$.
MCDOUGALL, K., 1979. Paleoecological evaluation of Late Eocene biostratigraphic zonations of the West Coast. U.S. Geol. Surv. Open-File Rept. 79-934:206 pp.

O'MEARA, E., 1877. On the diatomaceous gatherings made at Kerguelen's Land by H. N. Mosely, M.A., H.M.S. Challenger. Jour. Linnean Soc. (Bot.), 15 (82):55-59.

PANTOCSEK, J., 1886-1892. Beiträge zur Kenntniss der fossilen Bacillarien Ungarns. Teil I. Marine Bacillarien, 1-76, pls. 1-30 (1886). Teil II. Brackwasser Bacillarien. Anhang: Analyse der marine Depots von Bory, Bremia, Nagy-Kurtos in Ungarn; Ananio und Kusentzk in Russland, 1-123, 30 pls. (1889). Teil III. Süsswasser Bacillarien. Anhang-analysen 15 neuer Depots von Bulgarien, Japan, Mahren, Russland und Ungarn, 1-118, 42 pls. (1892). Nagy Tapolosany, Julius Platsko. Edition 2. Berlin: A. Junk, 1903-1905.

PERAGALLO, H. and PERAGALLO, M., 1897-1908. Diatomées Marines de France et des Districts Maritimes Voisins. Grez-sur-Loing (S. et M.). (Le Micrographe Préparateur, 1897-1908.) Text 491 pp. +48 pp. Atlas, 137 pls. (pls. 1-24, 1897; 25-48, 1898; 49-72, 1899; 73-80, 1900; 81-96, 1901; 97-110, 112-113, 1902; 124131,$1904 ; 132-135,1905 ; 120-123,136-137,1907 ; 114-119$, $111,1908)$.

POORE, R. Z., MCDOUGALL, K., BARRON, J., BRABB, E., and KLING, S., 1981. Microfossil biostratigraphy and biochronology of the type Relizian and Luisian Stages of California. In: Garrison, R. E., Ed., The Monterey Formation and related siliceous rocks of California. Soc. Econ. Pal. and Mineral., Pacific Sect., Los Angeles, California, 1981.

PRITCHARD, A., 1861. A history of infusoria, living and fossil arranged according to "Die Infusionsthierchen" of C. G. Ehrenberg; containing colored engravings illustrative of all the genera, etc.: viii + 1-968 pp., pls. 1-12. London: Whittaker and Co.

\section{PLATE 7}

1, 8 Denticulopsis hustedtii (Simonsen and Kan1, sample L27, length $35 \mu \mathrm{m} ; 8$, sample L27, length $16 \mu \mathrm{m}$.

2-4 Denticulopsis hyalina (Schrader) Simonsen 2, sample L24, length $31 \mu \mathrm{m} ; 3$, sample L23, length $26 \mu \mathrm{m} ; 4$, sample L24, length $23 \mu \mathrm{m}$.

5 Denticulopsis lauta (Bailey) Simonsen Sample L24, length $20 \mu \mathrm{m}$.

6 Denticulopsis nicobarica (Grunow) Simonsen Sample L17, length $17 \mu \mathrm{m}$.

7 Denticulopsis punctata (Schrader) Simonsen Sample L24, length $20 \mu \mathrm{m}$.

9-10 Rouxia diploneides Schrader 9. sample L24, length $64 \mu \mathrm{m} ; 10$, sample L2, length $72 \mu \mathrm{m}$.
11-12 Thalassiothrix longissima Cleve and Grunow 11 , sample L9, length $70 \mu \mathrm{m} ; 12$, sample L9, length $80 \mu \mathrm{m}$.

13 Synedra jouseana Sheshukova-Poretskaya Sample L21, length $80 \mu \mathrm{m}$.

14 Entopyla australis var. gigantea (Greville) Fricke Sample L10, length $122 \mu \mathrm{m}$.

15 Mediaria splendida Sheshukova-Poretskaya Sample L21, length $105 \mu \mathrm{m}$.

16 Nitzschia challengeri Schrader Sample L18, length $50 \mu \mathrm{m}$.

17-18 Delphineis angustata (Pantocsek) Andrews 17 , sample L2, length $55 \mu \mathrm{m} ; 18$, sample L2, length $45 \mu \mathrm{m}$.

19 Rhaphoneis amphiceros Ehrenberg Sample L1, length $35 \mu \mathrm{m}$. 

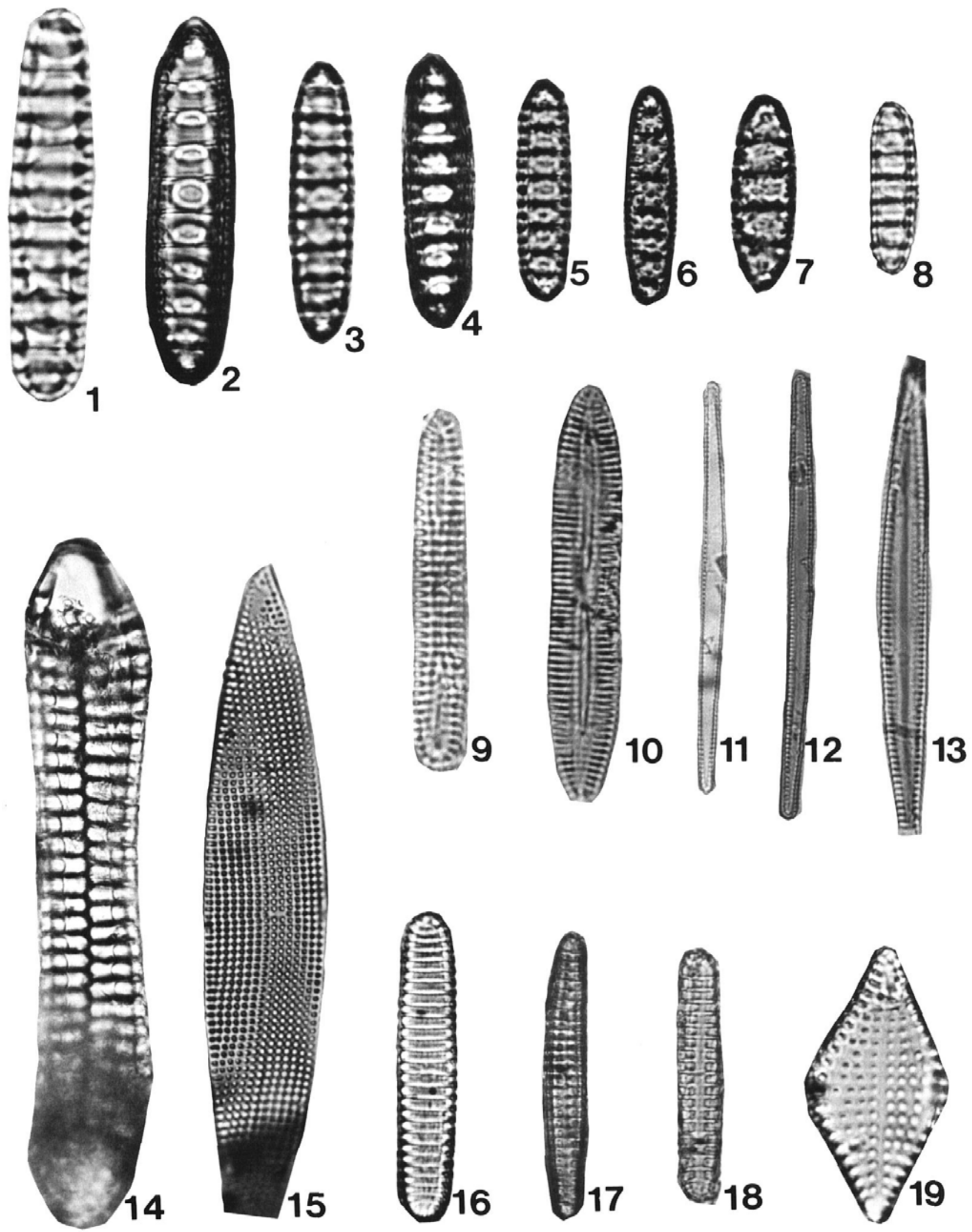
PROSCHKINA, J. S., and LAVRENKO, A. I., 1949. Diatomovyi Analis. Part 2. Opredelitel'Iskopaemykh i Sovremennykh Diatomovykh Vodorosle, Poryadok Centrales i Mediales, sostavili-A. P. Jousé (pp. 14-224, pls. 1-101), I. A. Kisselev (pp. 14-209), V. S. Poretzky (pp. 14-209), A. I. Proschkina-Lavrenko (pp. 210-224) i V. S. Sheshukova. Botanicheskii Institut im V. L. Komarova Akademii Nauk S.S.S.R., 238 pp. Moskva-Leningrad: Gosudarstvennoe Izdatelystvo Geologicheskoi Literatury.

RATTRAY, J., 1890a. A revision of the genus Coscinodiscus Ehrb., and of some allied genera. Roy. Soc. Edinburgh, Proc., 16:449692,3 pls. Separate pagination, 1-244 pp., 3 pls. Edinburgh: Neill and Company.

1890b. A revision of the genus Actinocyclus Ehrenberg. Quekett Micr. Club, Jour., ser. 2, 4:137-212, pl. 11.

REINHOLD, T., 1937. Fossil diatoms of the Neogene of Java and their zonal distribution. Geol.-Mijnbouw. Genoot. Nederlanden Kolonien, Verhandel., Geol. Ser., 12(1):43-133, pls. 1-21.

ROPER, F. C. S., 1859. On the genus Biddulphia and its affinities. Micros. Soc. London, Trans., 7:1-24.

SCHMIDT, A., 1874 (1875). Die in den Grundproben der Nordseefahrt vom 21 July bis 9 Sept. 1872 enthaltenen Diatomaceen. Erste Folge. Separatabdr. aus d. Ilte Jahresber. der Komm. z. Untersuchung d. deuts. Meere, 2-3:81-95. Kiel.

SCHMIDT, A., et al., 1874-1959. Atlas der Diatomaceen-Kunde. Leipzig: R. Reisland. Nos. 1-120, tables 1-460 (1-216. A. Schmidt; 213-216, M. Schmidt; 217-240, 1900-1901, F. Fricke; 241-244, 1903, H. Heiden; 245-246, 1904, Otto Müller; 247256, 1904-1905, F. Fricke; 257-264, 1905-1906, H. Heiden; 265-268, 1906, F. Fricke; 269-471, 1911-1959, F. Hustedt).

SCHRADER, H.-J., 1973. Cenozoic diatoms from the northeast Pacific, Leg 18. In: Kulm, L. D., von Huene, R., et al., Initial Reports of the Deep Sea Drilling Project, volume 18:673-797. Washington, D.C.: U.S. Government Printing Office.

1974. Revised diatom stratigraphy of the Experimental Mohole Drilling, Guadalupe Site. California Acad. Sci., Proc., ser. 4, 39:517-562.

1978. Diatoms in DSDP Leg 41 sites. In: Lancelot, Y., Seibold, E., et al., Initial Reports of the Deep Sea Drilling Project, volume 41:791-812. Washington, D.C.: U.S. Government Printing Office.

SHACKLETON, N. J., and KENNETT, J. P., 1975. Paleotemperature history of the Cenozoic and the initiation of Antarctic glaciation: Oxygen and carbon isotope analyses in DSDP sites 277, 279, and 281. In: Kennett, J. P., Houtz, R. E., et al., Initial Reports of the Deep Sea Drilling Project, volume 29:743-775. Washington, D.C.: U.S. Government Printing Office.

SHESHUKOVA-PORETZKAYA, V. S., 1962. Novie i redkie Bacillariophyta iz diatomovoi sviti Sakhalina. Uchenie Zapiski Igu, Ser. Biol., Nauk (Leningrad Univ.), 49(313):203-211.
1967. Neogene marine diatoms of Sakhalin and Kamchatka. Izd. Leningrad Univ., 1-327, pls. 1-50.

SIMONSEN, R., 1979. The diatom system: Ideas on phylogeny, Bacillaria 2. Germany: Braunschweig, J. Cramer, 9-79.

SIMONSEN, R., and KANAYA, T., 1961. Notes on the marine species of the diatom genus Denticula Kütz. Internat. Rev. Ges. Hydrobiol., 46(4): 498-513.

SMITH, WM., 1853, 1856. Synopsis of British Diatomaceae. London: John van Voorst, 1:1-89 (1853); 2:1-104 (1856).

TEMPĖRE, J., and PERAGALLO, H., 1907-1915. Diatomées du Monde Entier, Edition 2, 30 fascicules. Paris, France: Arcachon, $1-480$.

VAN HEURCK, H., 1880-1885. Synopsis des Diatomées de Belgique. Atlas, pls. 1-132 + A-C. Anvers: Ducaju et Cie.

, 1896. A Treatise on the Diatomaceae. Translated by W. E. Baxter. London: William Wesley \& Son, 558 pp., 35 pls.

VAN LANDINGHAM, S. L., 1967. Catalogue of the fossil and Recent genera and species of diatoms and their synonyms. (A revision of F. W. Mills, "An Index to the Genera and Species of the Diatomaceae and their Synonyms.") Part I. Acanthoceras through Bacillaria, 493 pp. Weinheim, Germany: Verlag von J. Cramer.

WARREN, A. D., 1972. Luisian and Mohnian biostratigraphy of the Monterey Shale at Newport Lagoon, Orange County, California. In: Steinmeyer, E., Ed., The Pacific coast Miocene biostratigraphic symposium. Soc. Econ. Pal. Mineral., Pacific Sec., Los Angeles, 27-36.

WOLLE, F., 1890. Diatomaceae of North America. Bethlehem, PA: The Comenius Press, 1-47.

WOODRUFF, F., SAVIN, S. M., DOUGLAS, R. G., and SHAUGHNESSY, L., 1979. High resolution study of major mid-Miocene climatic events in west Pacific Ocean sediment. Geol. Soc. Amer., Abs. Prog., 1979 Annual Meeting, 11(7):544.

WORNARDT, W. W., JR., 1967. Miocene and Pliocene marine diatoms from California. California Acad. Sci., Occas. Papers, 63:1108.

1973. Diatom, silicoflagellate, radiolarian, calcareous nannofossil, and foraminiferal biostratigraphy of the Middle and Late Miocene and Pliocene of Newport Back Bay, Newport Beach, California. Guidebook SEPM Trip 1, Miocene and sedimentary environments and biofacies, southeastern Los Angeles Basin. Amer. Assoc. Petr. Geol., Soc. Econ. Pal. Mineral., Soc. Explor. Geophys., 1973 Annual Meeting, 39-53.

YEATS, R., HAQ, B. U., et al., 1981. Initial reports of the Deep Sea Drilling Project, volume 63:961 pp. Washington, D.C.: U.S. Government Printing Office.

Manuscript received January 12, 1981. 